\title{
آليات تسوية العقار الفلاحي محل الاستصلاح في إطار ترقية الاستثمار في الجزائر
}

Settlement Mechanisms of agricultural lands that are subject of reclamation in the framework of the promotion of investment in Algeria

\author{
تاريخ الاستلام : 2019/09/28 ؛ تاريخ القبول : 2020/04/04
}

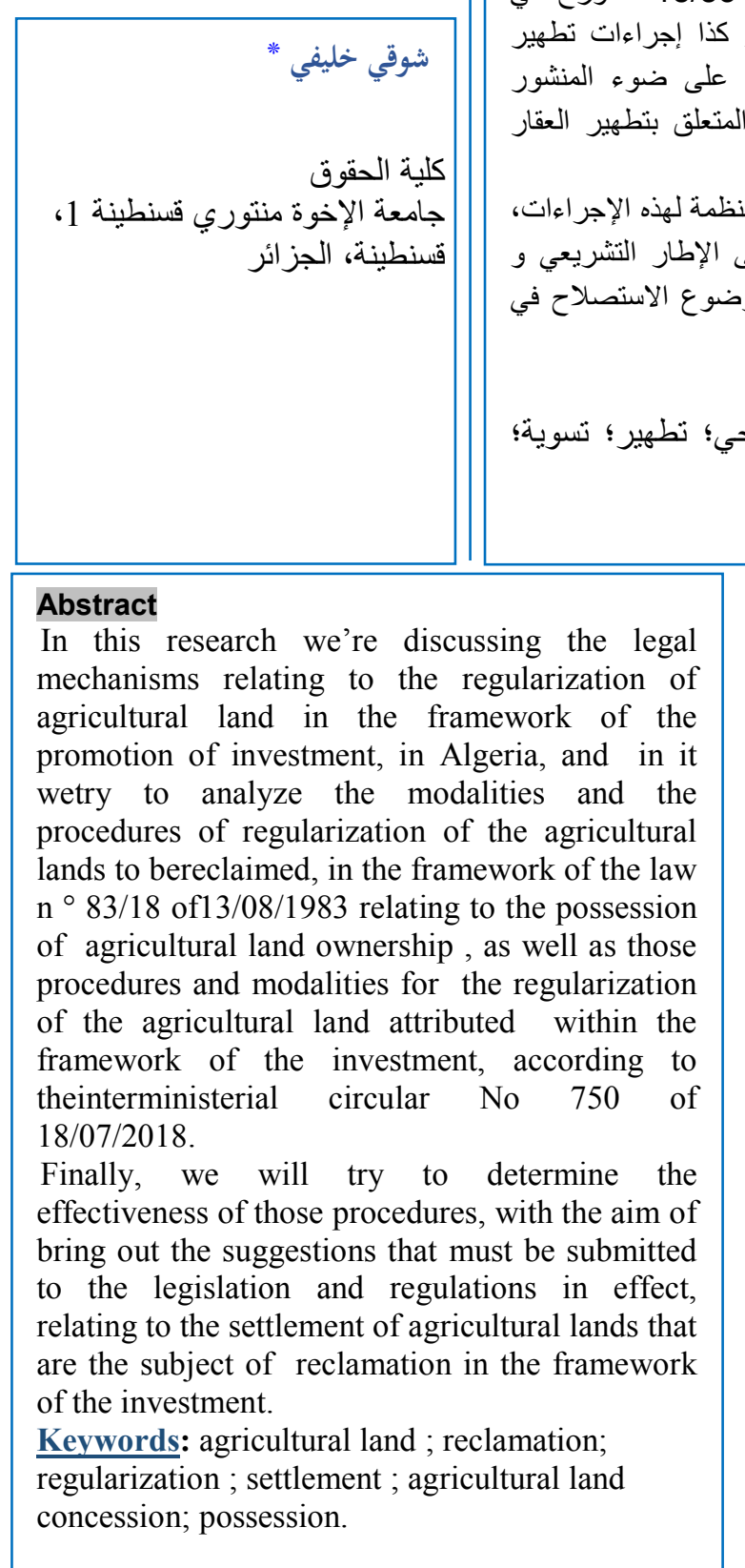

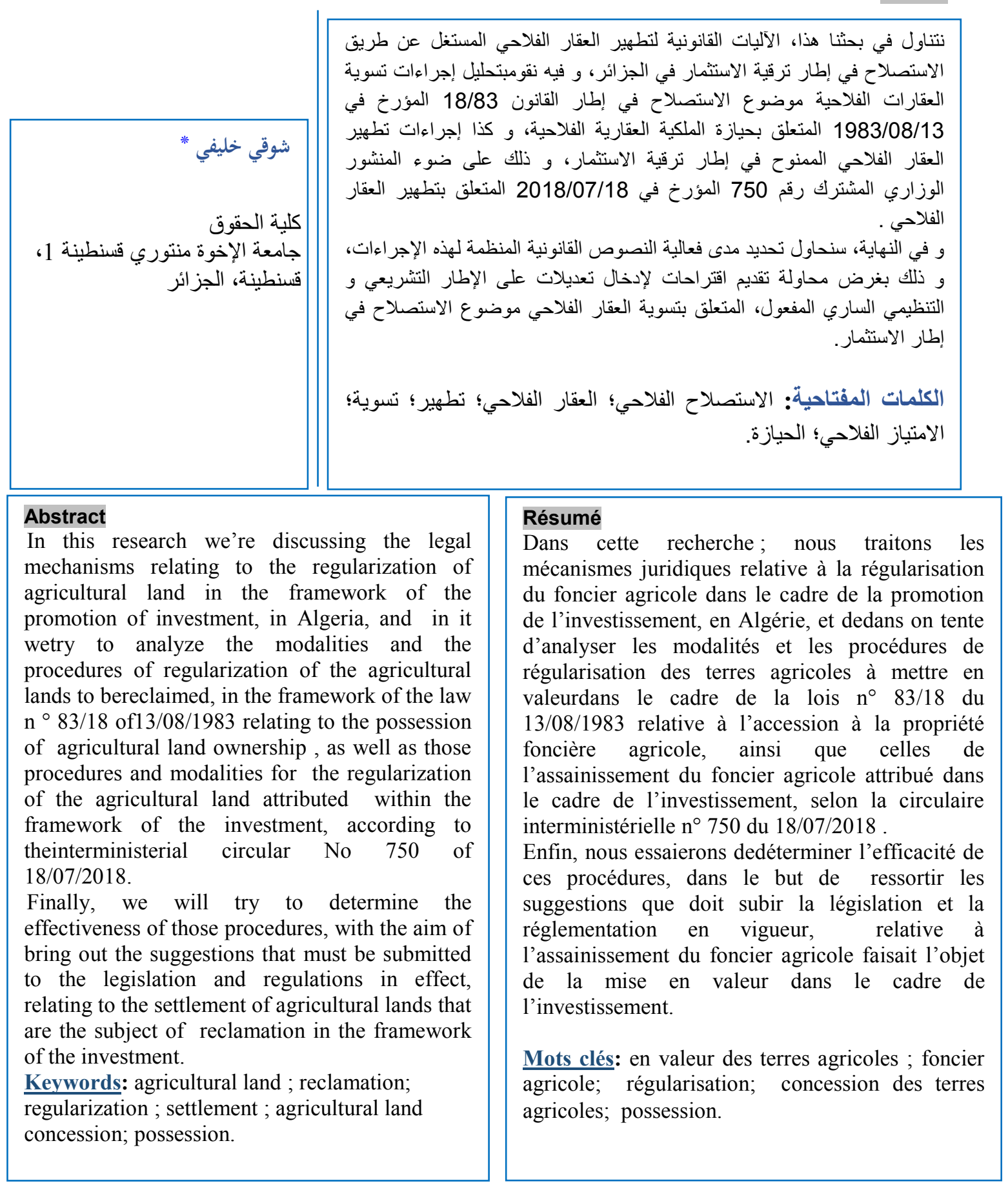

* Corresponding author, e-mail: romamilev@gmail.com 
ارتبط الاستصلاح الفلاحي في الجزائر بمتغيرات سياسية و أخرى إيديولوجية

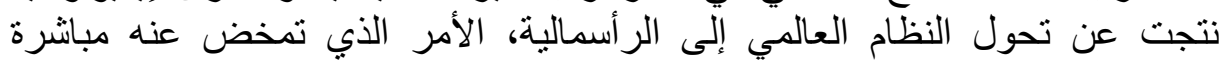
إصلاحات هيكلية في القطاع الفلاحي، تهدف إلى تبني إستراتئية التية جديدة تقوم على التي تطهيره، و ذلك بإخراجه و لو جزئيا من الملكية المطلقة للاولة، و بلتئية بالتبعية تحرير

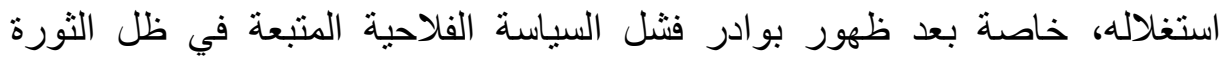

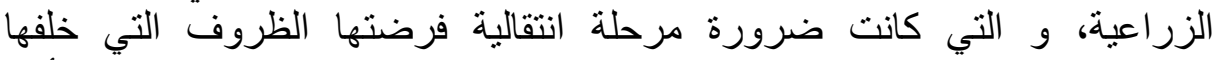

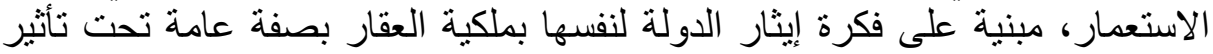
المفهوم السياسي الذي يربط الأرض بالسيادة، فهذه الأخيرة أحد مكونات الدولة طبة طبة الفيا

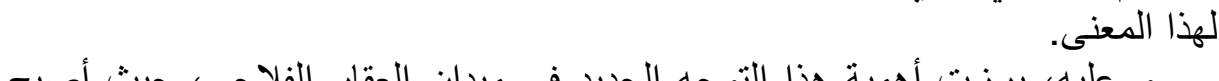
و عليه، برزت أهمية هذا التوجه الجديد في ميدان العقار الفلاحي، حيث أصبح

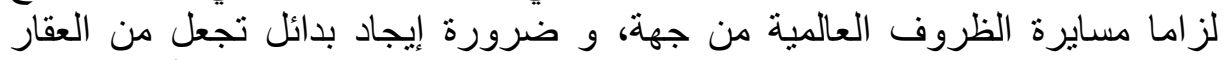

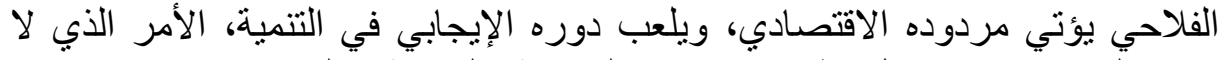

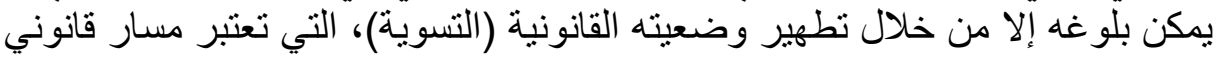

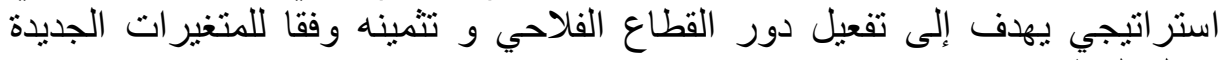

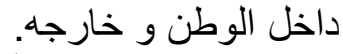

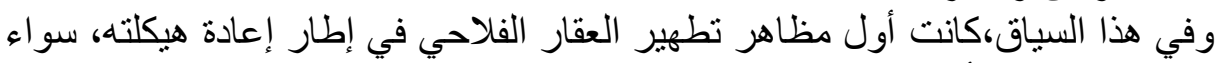

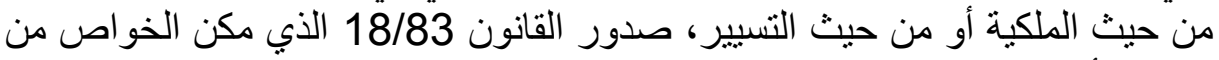

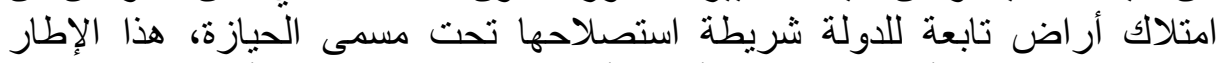

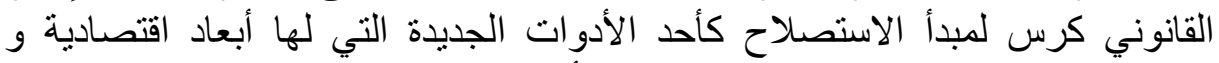

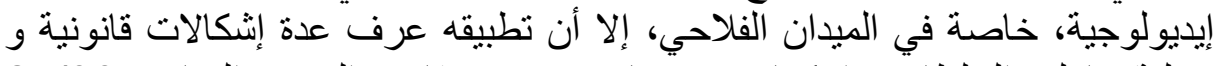

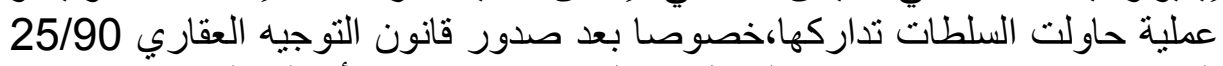

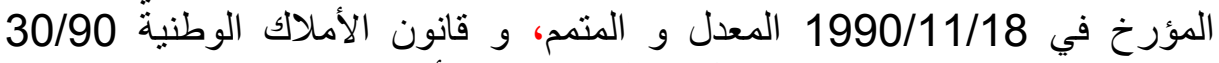

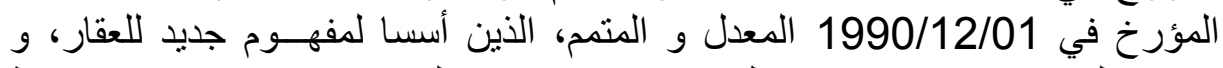

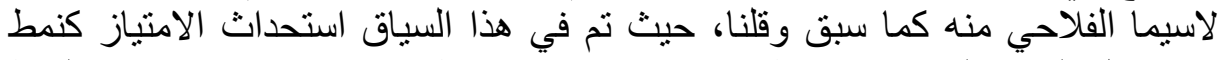

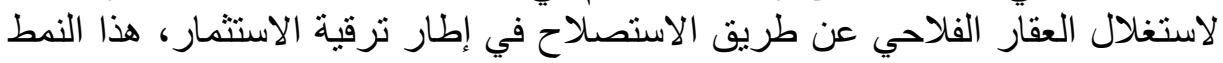

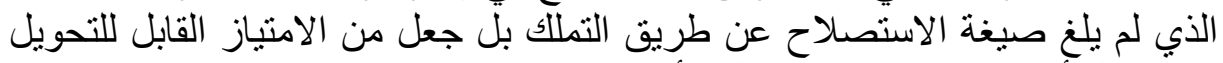

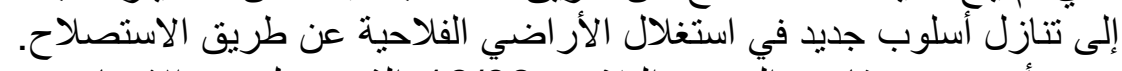

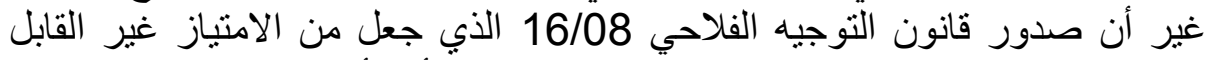

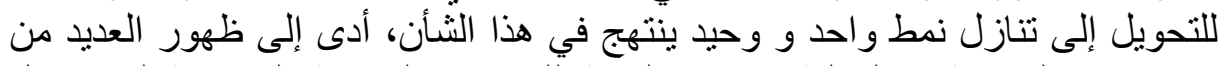

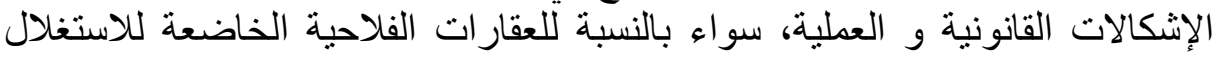

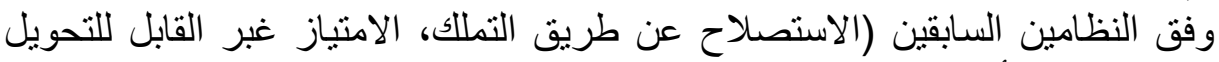

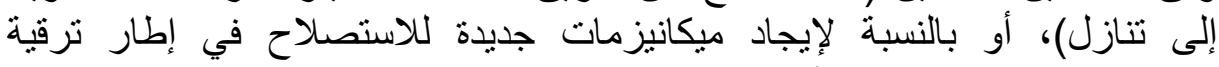
الاستثمار بما يتو افق و هذا القان القانون. كل هذا، فرض على السلطات العليا في الدولة إيجاد آليات لتطهير هذه الوضعيات عن طريق تسويتها القانونية،و هو ماتبلور في إصدار العديد من النصوص القانونية في هذا

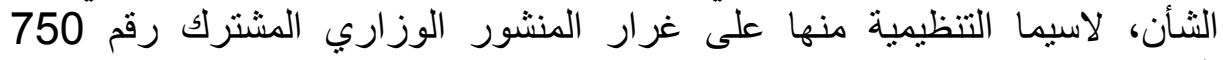

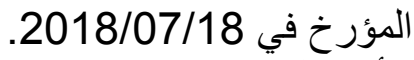

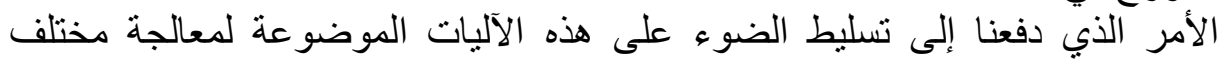

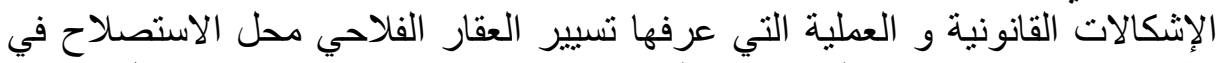

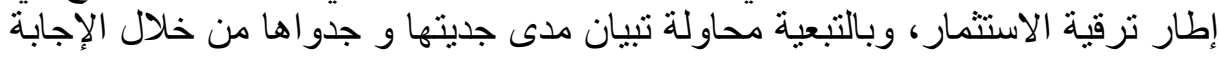

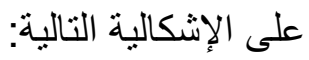




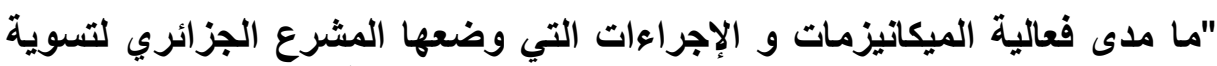
العقار الفلاحي المستغل عن طريق الاستصلاح في إطار ترقية الاستثمارب؟".

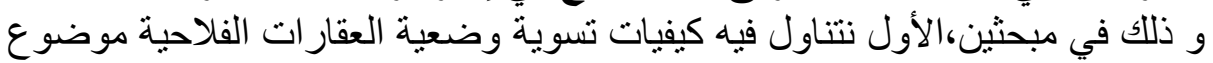

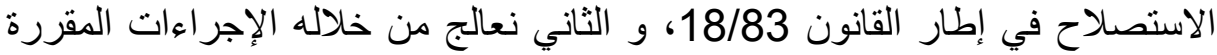
لتسوية هذه العقار ات في إطار ترقية الاستثمار عن طريق الاستصات الإنصلاح في المحيطات،

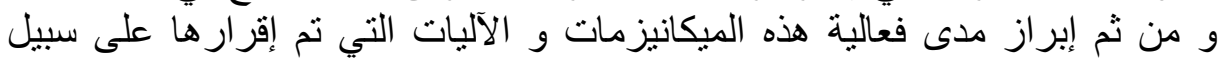
التسوية في هذا الثنأن.

المبحث الأول/ كيفيات تسوية الأراضي الفلاحية موضوع الاستصلاح في إطار القانون 18/83 المؤزخ في 1983/08/13: لقد عرف تطبيق القانون 18/83

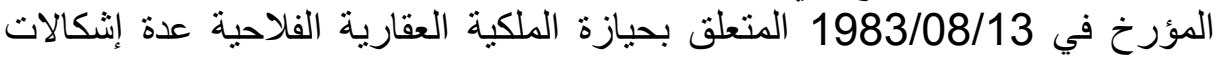

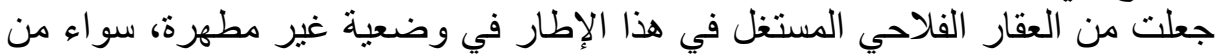

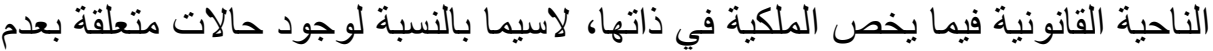

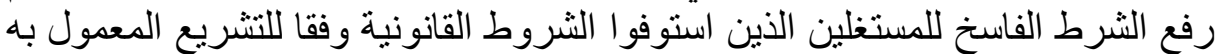

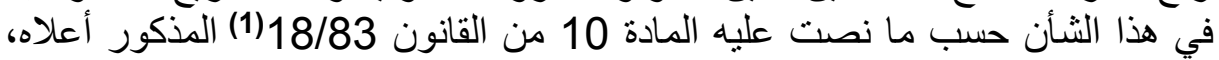

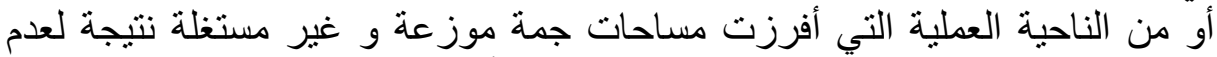

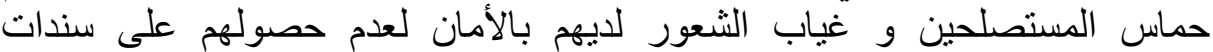

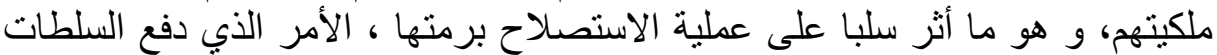

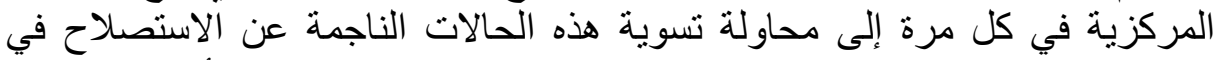

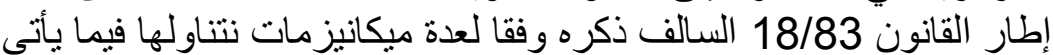

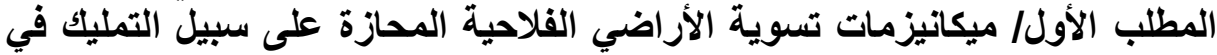

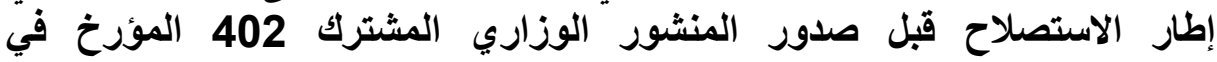

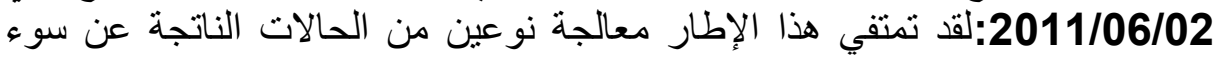
تطبيق قانون حيازة الملكية العقارية الفلاحية 18/83، و يتعلق الأمر باستصلاحات تم تم

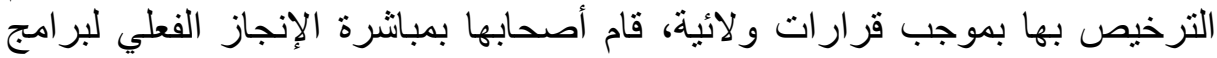

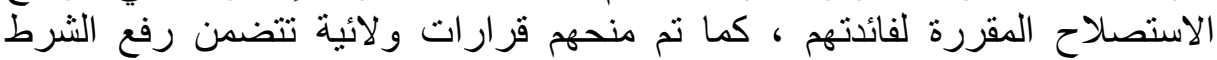

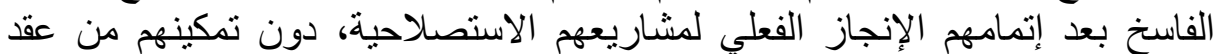

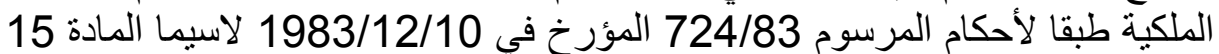

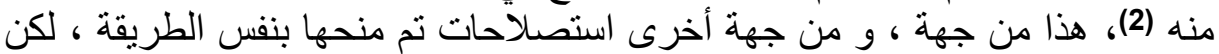

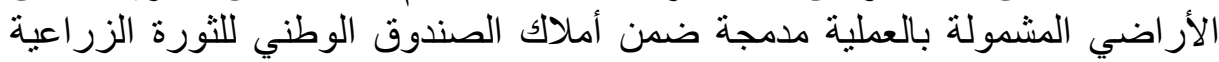

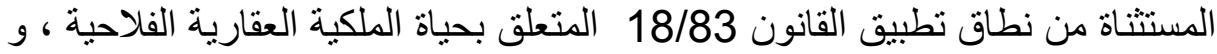

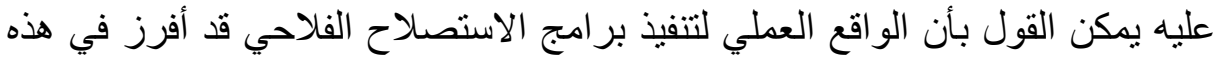

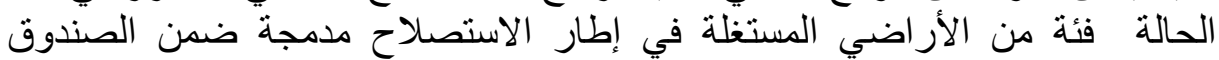

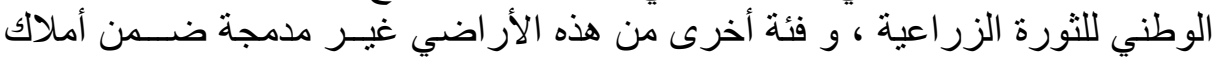

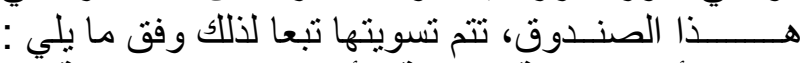

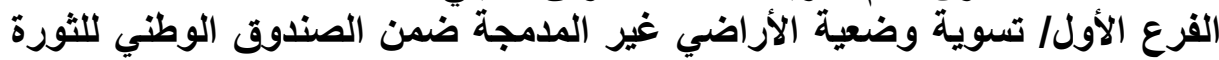

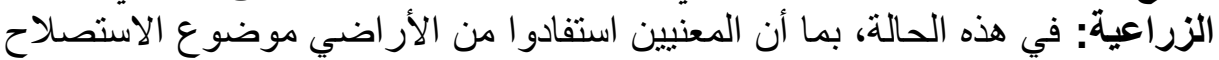

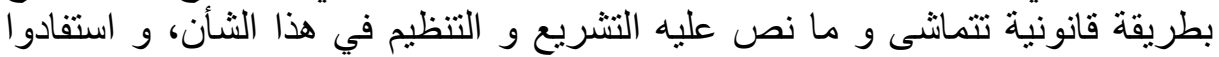

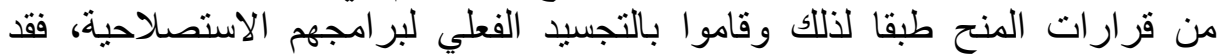

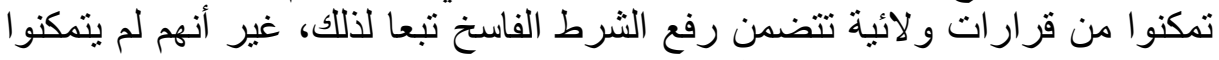

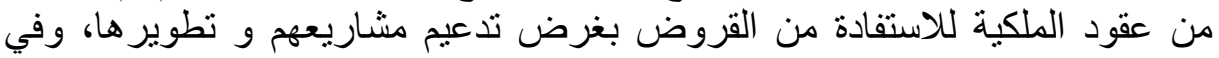

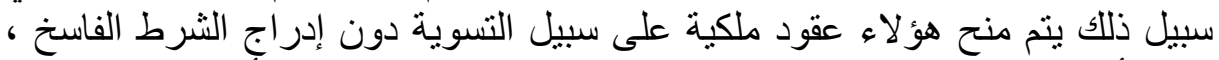

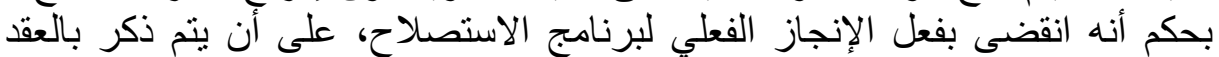

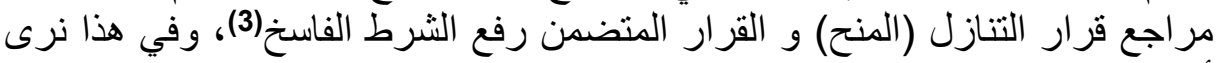
أن الإدارة قد وفقت إلى حد بعيد، في مقاربة عادلة منها لتسن التسوية هذه الحالات. 


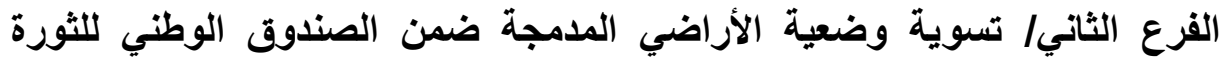

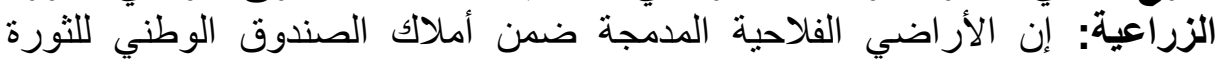

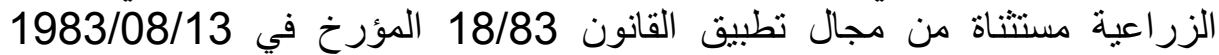

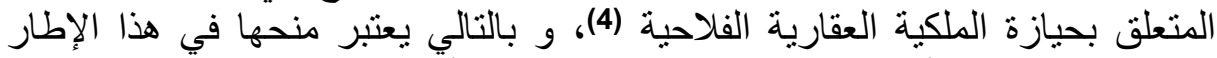

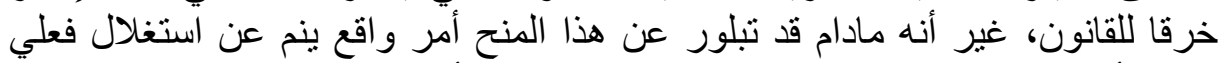

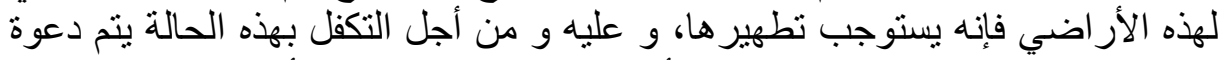

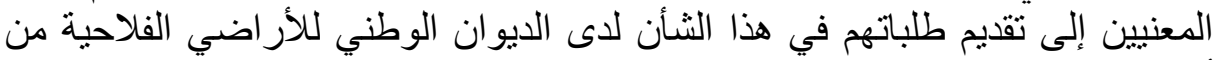

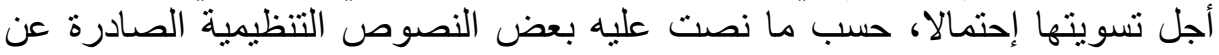

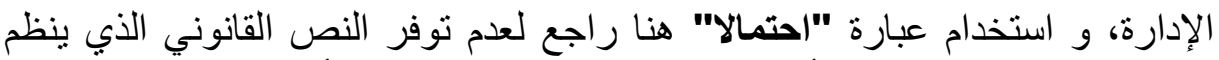

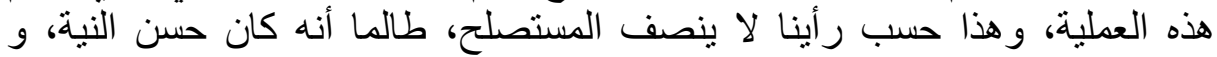

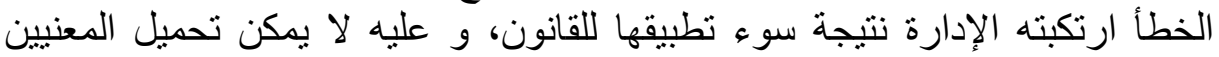

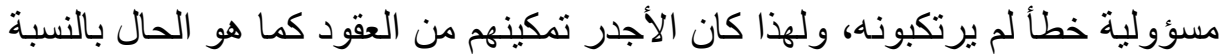

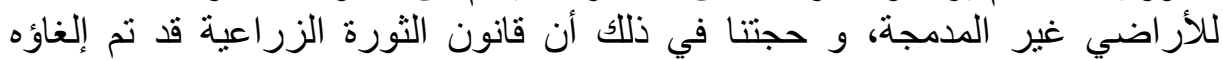

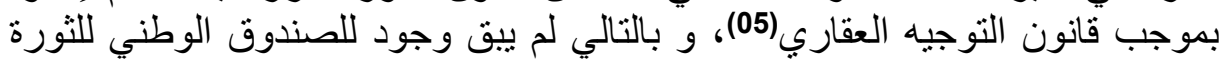

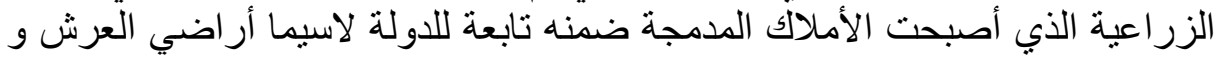

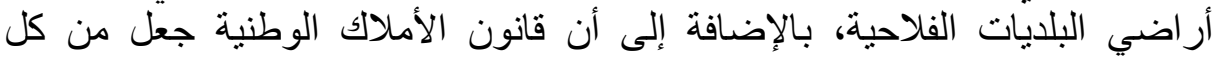

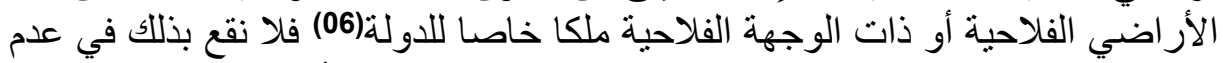

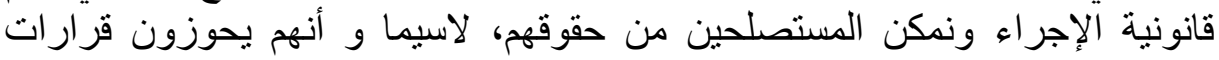

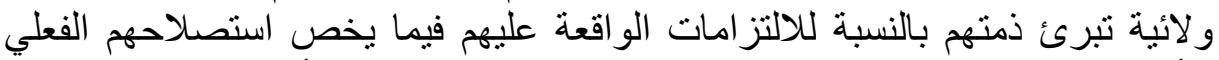

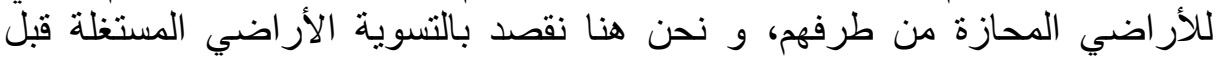

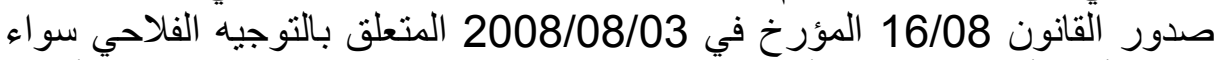

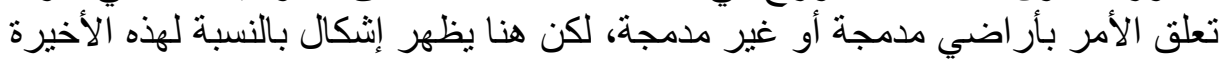

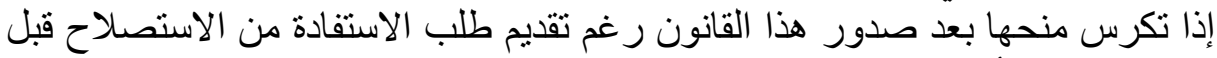

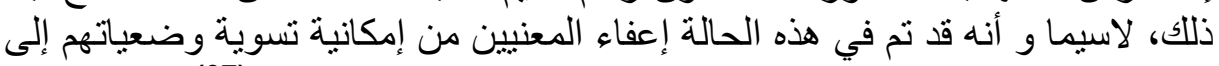

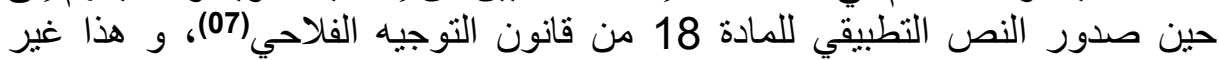

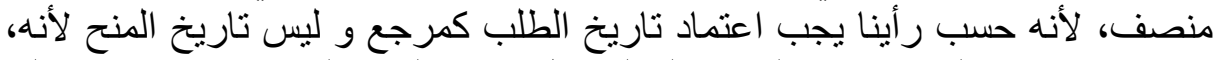

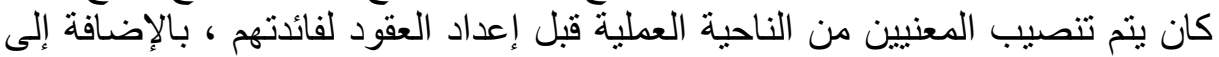

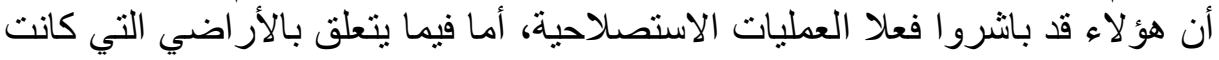

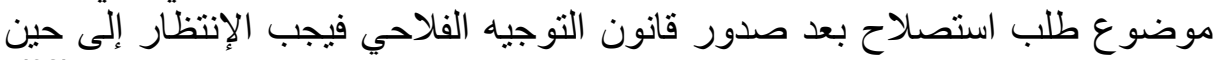

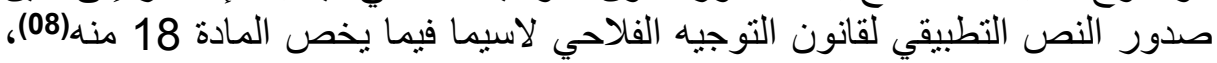

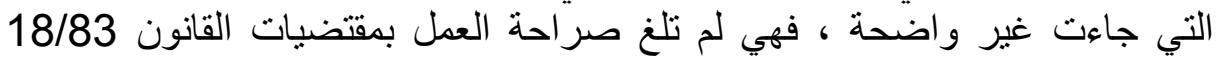

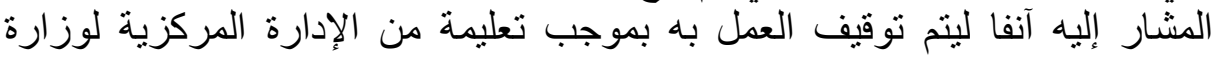

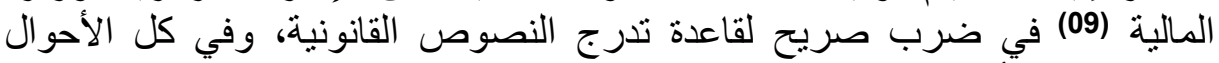

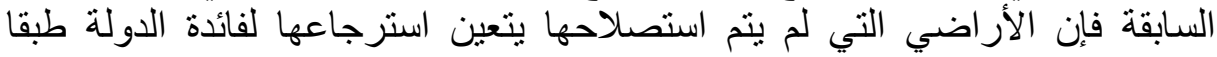

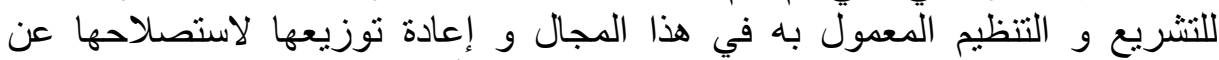

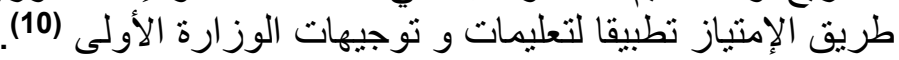

المطلب الثاني/ ميكانيزمات تسوية الأراضي الفلاحية المحازة على سبيل التمليك في

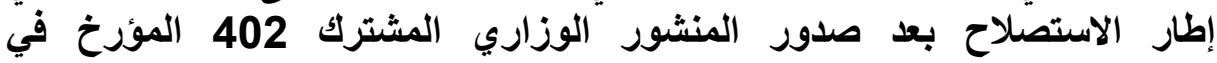

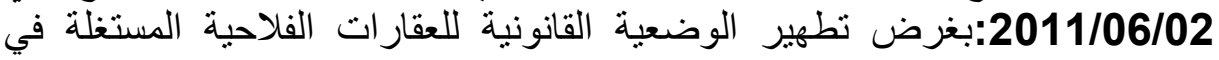

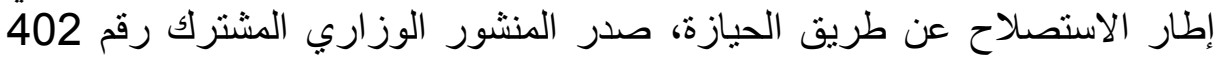
المؤرخ في 2011/06/02، الذي حاول تفعيل عمليات التطهير نتيجة لعدم جدوى التئن 
الإجراءات المتخذة من قبل في هذا الثأن، حيث تم التمبيز بين عدة حالات نتناولها

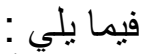

الفرع الأول/ الأراضي الفلاحية موضوع معاينة ميدانية:في إطار المتابعة الميدانية

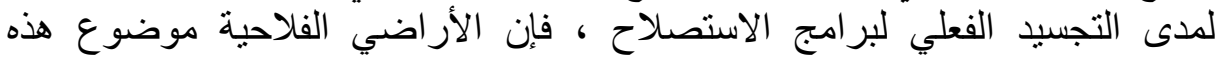

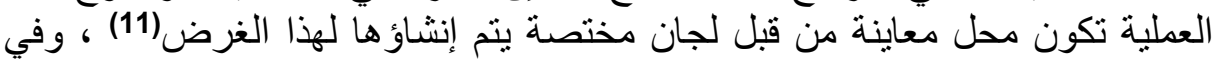

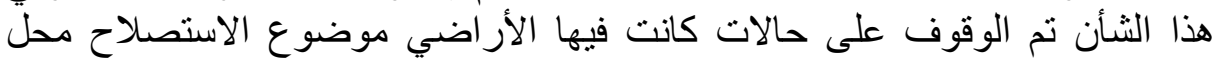

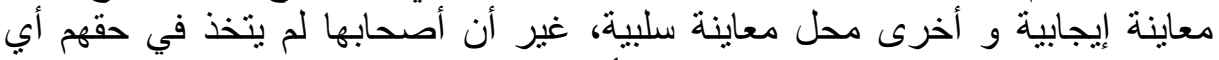

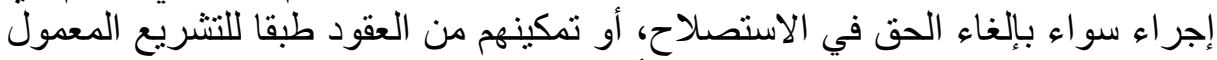
به، ما حتم تسوية هذه الوضعيات كما سيأتي تبيانه.

1/ حالة الأراضي الفلاحية التي كانت محل معاينة إيجابية دون أن يترتب عنها إعداد

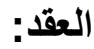
و هنا يقوم الوالي برفع الشرط الفاسخ بمقتضى قرار يتولى إعداده و إرساله إلى

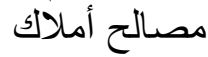
الدولة لغرض الحرير عقد الملكية و إخضاعه إلى شكليات التسجيل و الإشهار (12)، و هنا نقول أن المنشور الوزاري المشترك رقم 402 المتعلق بحيازة الملكية العقارية

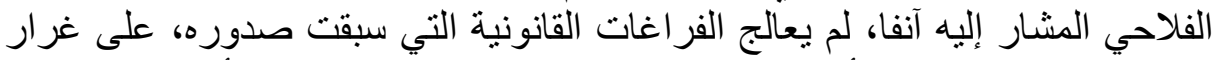

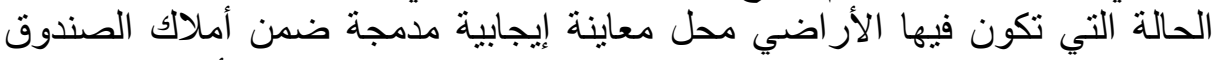

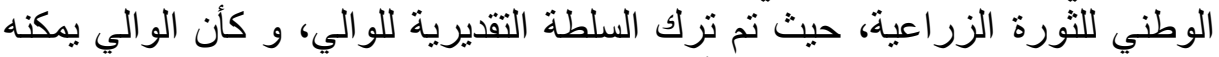

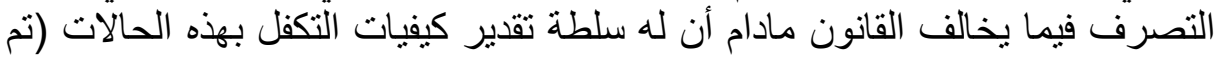

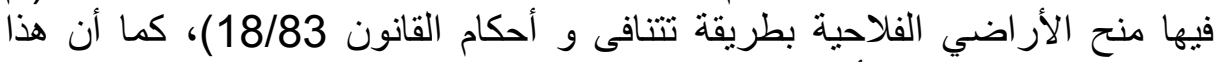

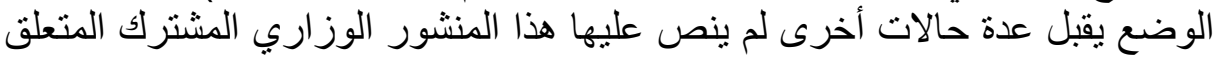
بتطهير الوضعيات القانونية الناجمة عن تطبيق قانون حيازة الملكية العقارية الفلاحية،

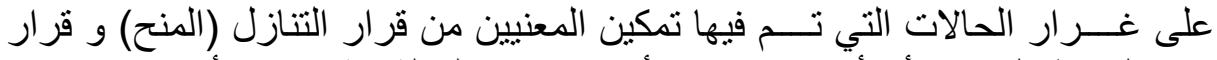

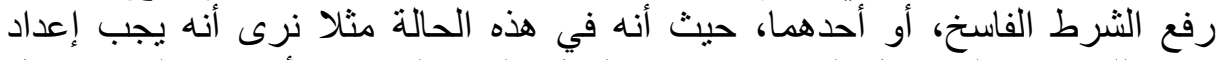

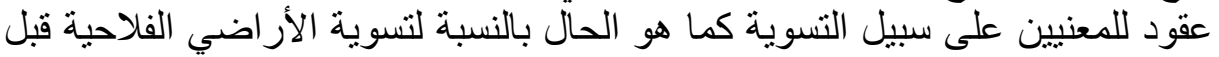

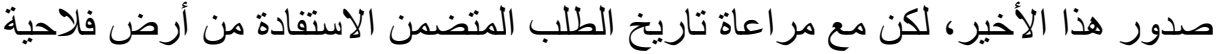

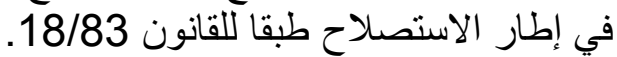

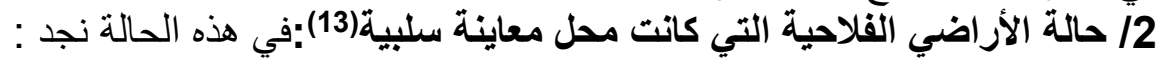

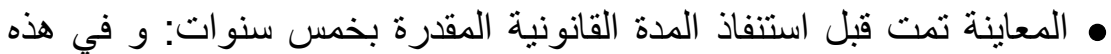

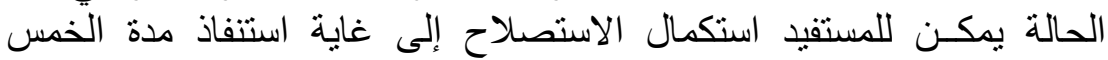

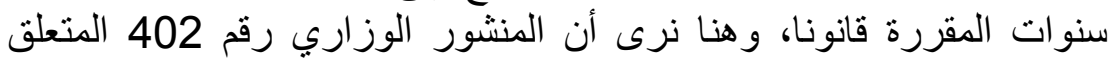

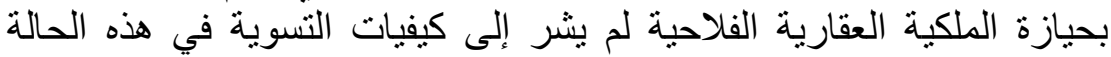

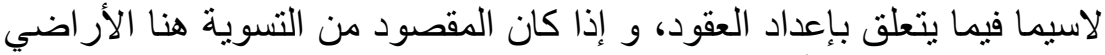

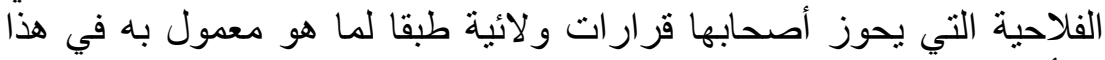

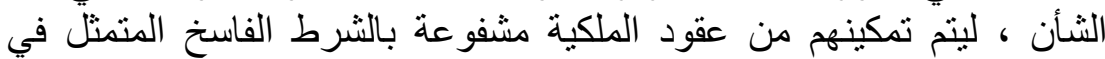

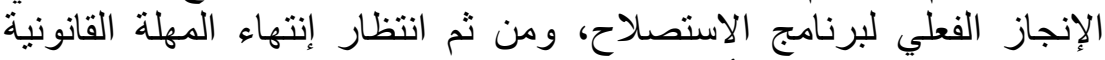

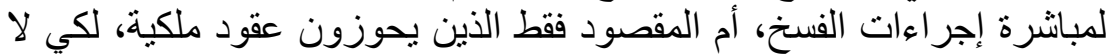

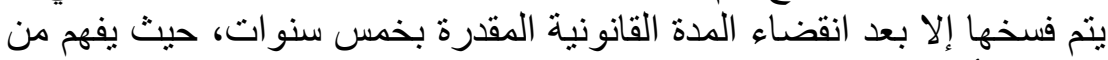

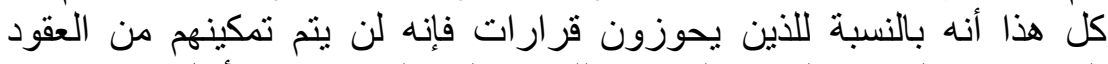

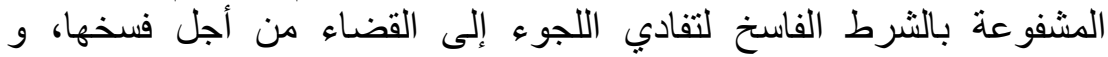
الاكتفاء بالقرارات التي يحوزونها لفسخها مباثرة بمقتضى قراء التهاء ولائي تطبيقا لقاعدة نوازي الأشكال 


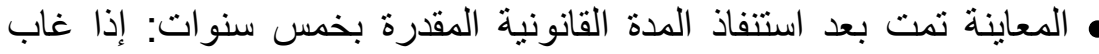

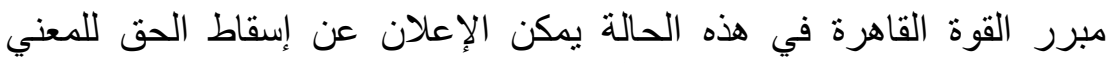

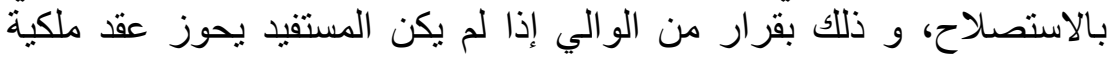

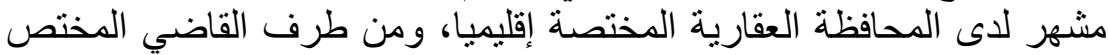
بناءا على طلب الو الي إذا كان في حوزته عقد ملكية مشهر، إذا لم لم يقم بالإنجاز

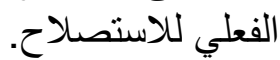
لكن و في ذات السياق، و في إطار التسوية دائما، نقول ما مصير أولئك الذين

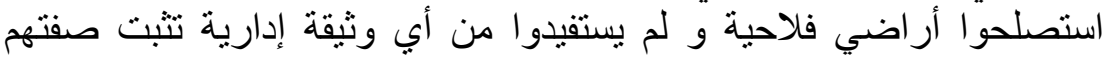

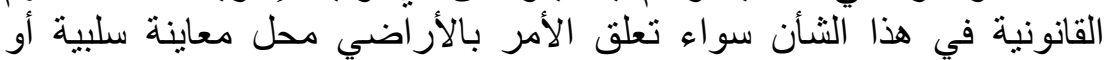

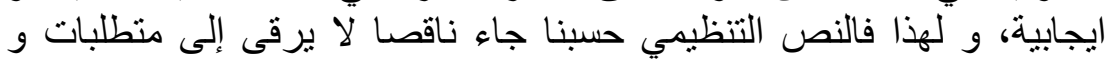

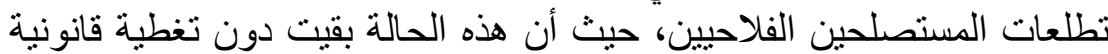

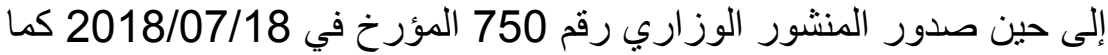

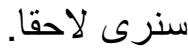

الفرع الثاني/ الأراضي الفلاحية التي لم تكن محل معاينة أو تم تحويل طابعها: لقد

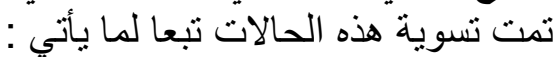

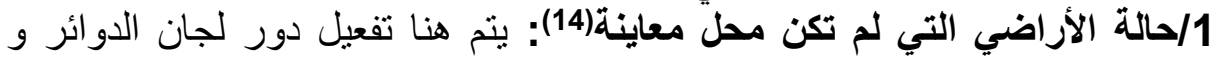

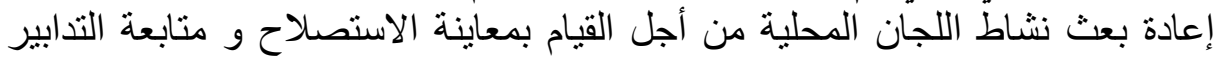

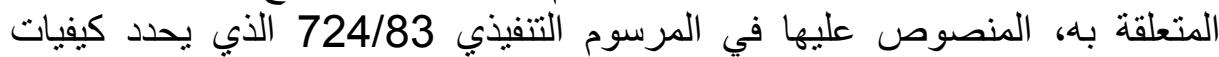

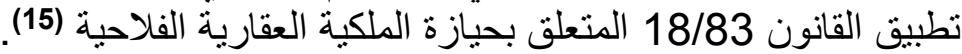

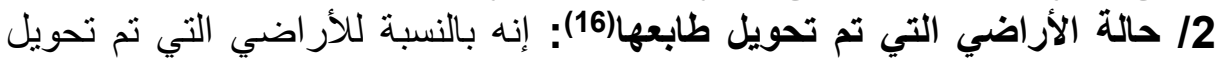

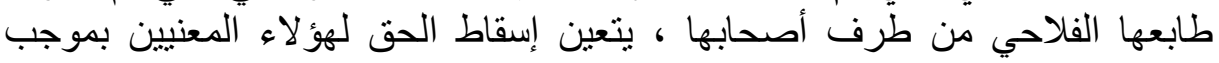

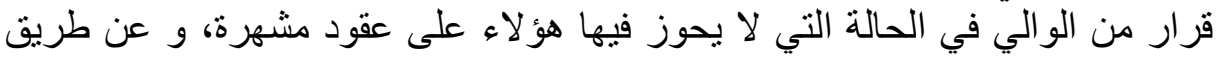

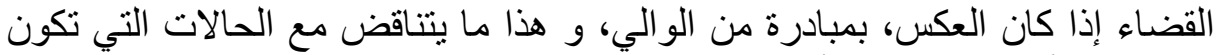

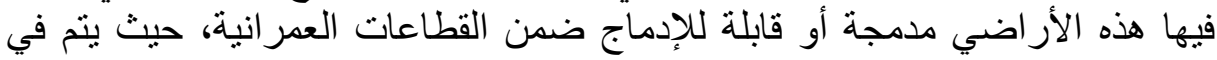

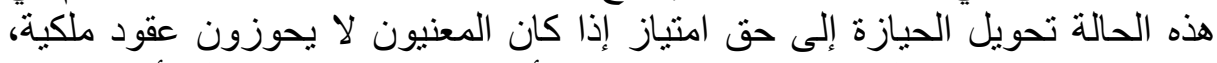

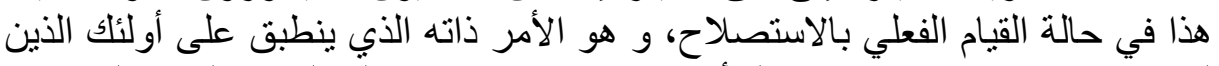

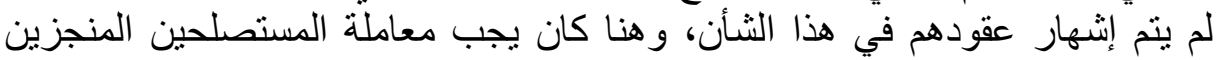

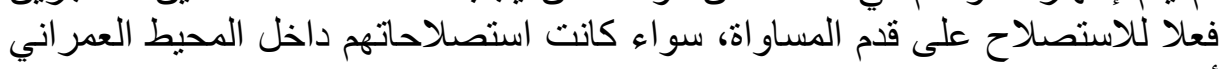

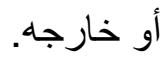

مما سبق نجد أن كل حالات التسوية لا تمس أولئك الذين تم تتصيبهم في المساحات

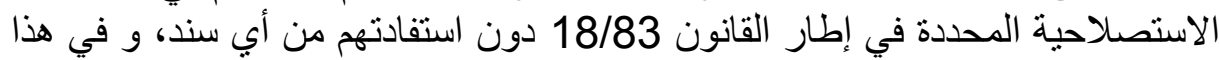

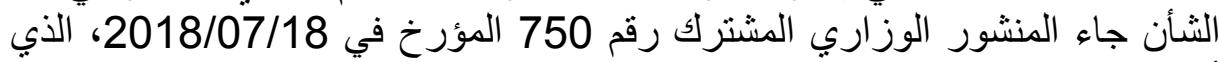

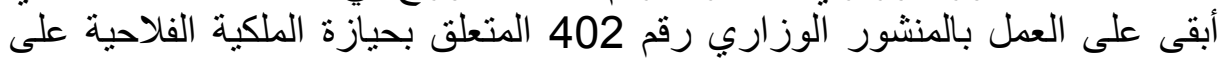

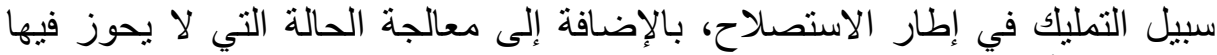

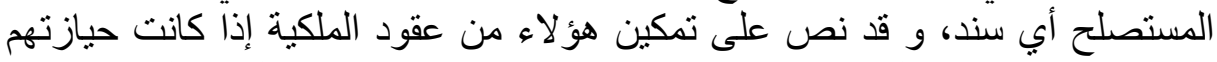

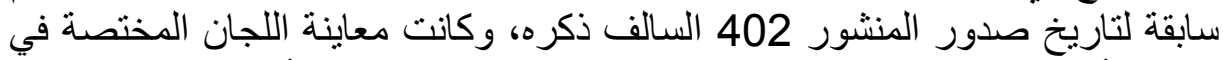

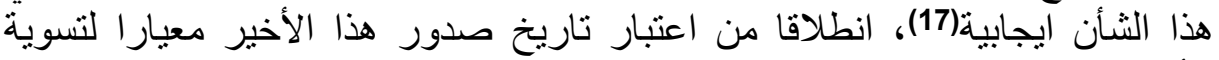

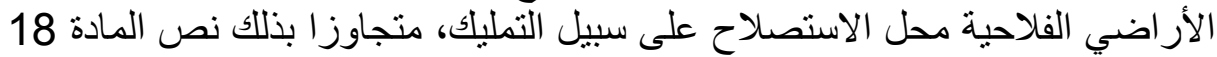

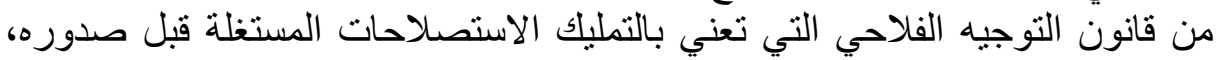

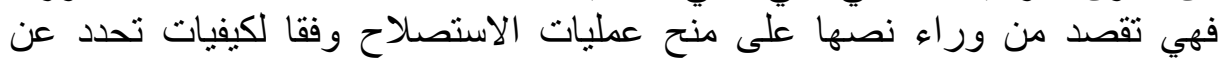

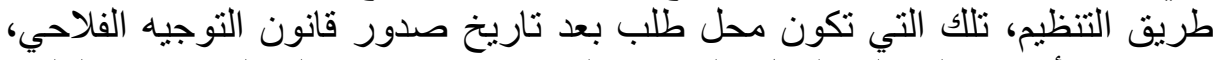

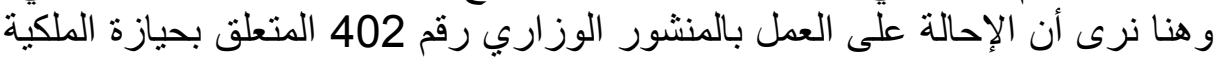
العقارية الفلاحية ينم عن عدة إنشالات أخرى، منها جعل نطبيق القانون 


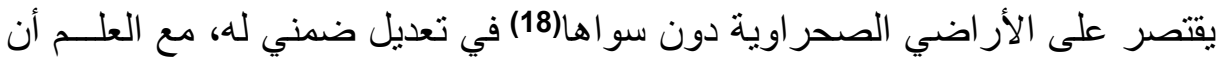

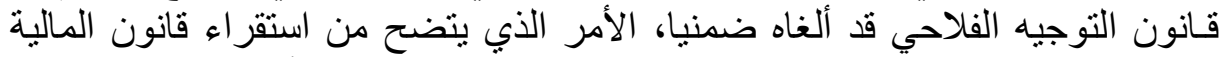

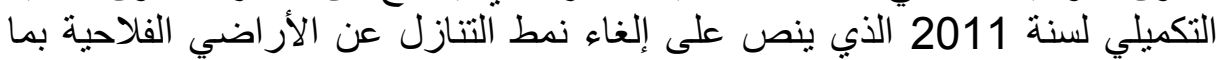

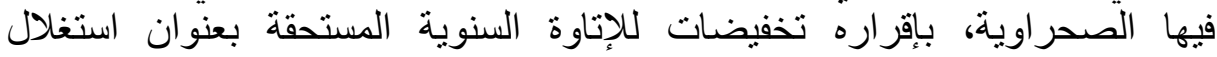

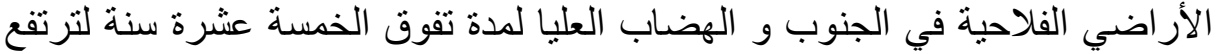

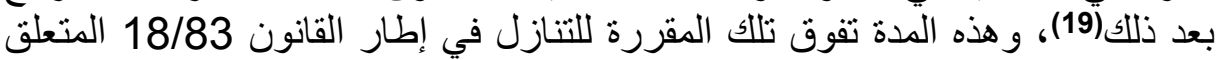

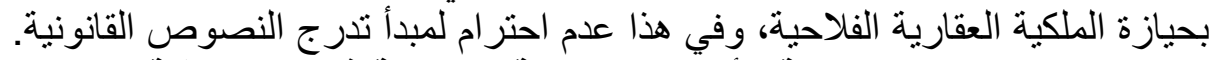

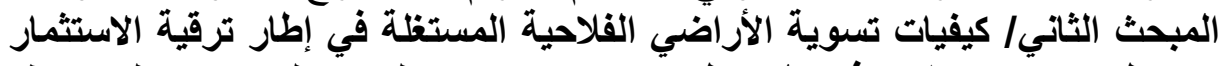

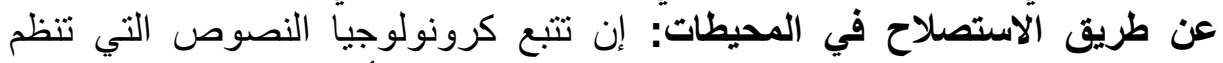

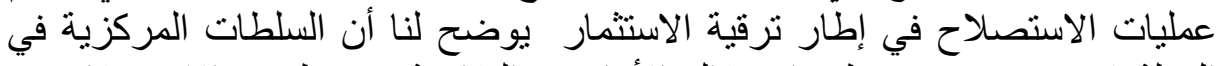

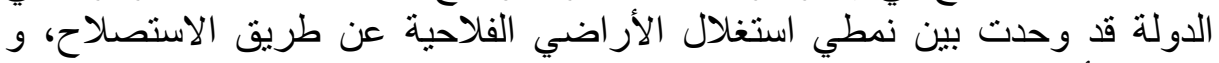

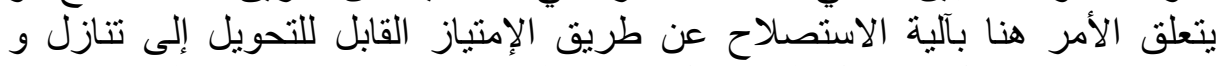

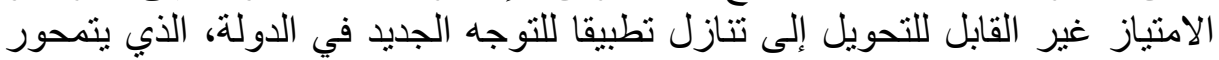

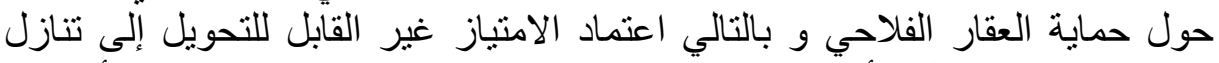

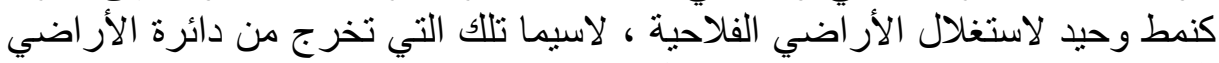

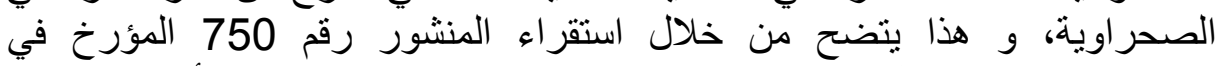

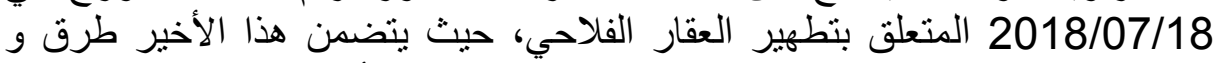
إجراءات تسوية الوضعيات المتعلقة بالعقارات الفلاحية أو ذات الفوات الوجهة الونية الفلاحية

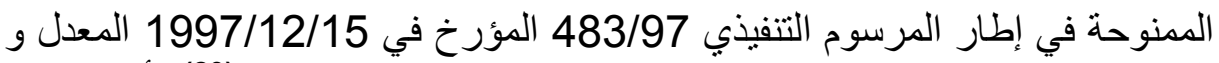
المنمم بالمرسوم التنفيذي رقم 372/98 المؤرخ في

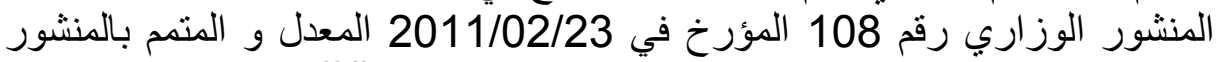

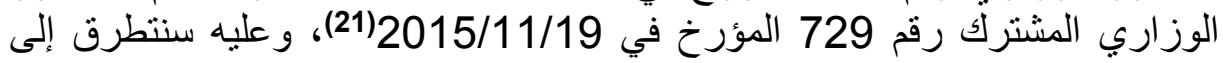

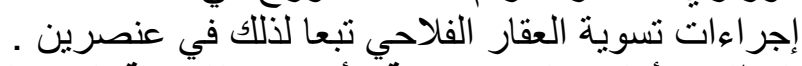

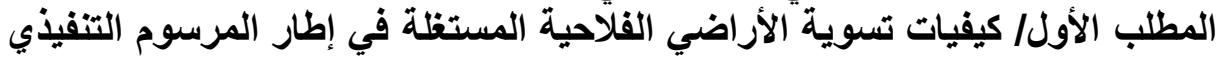

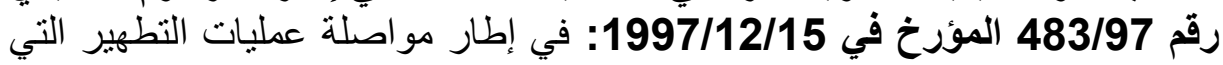

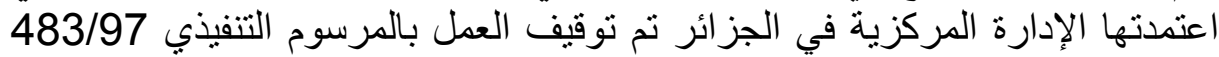

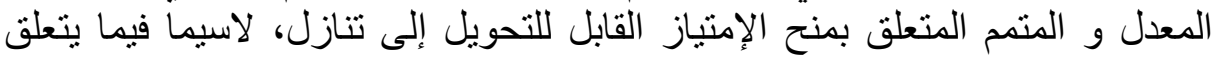

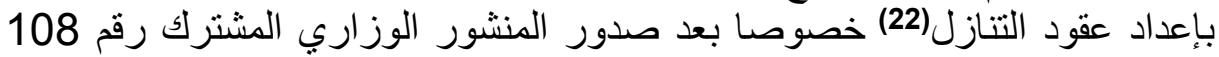

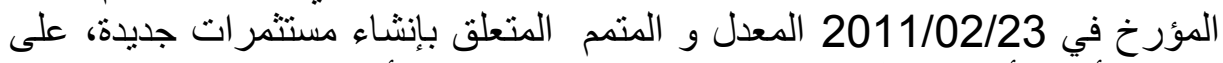

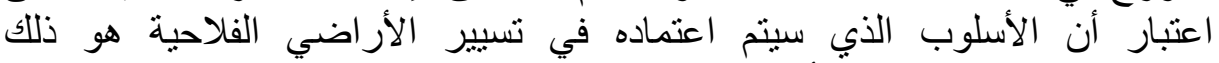

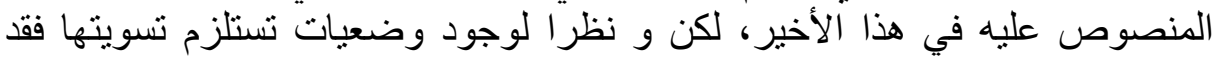

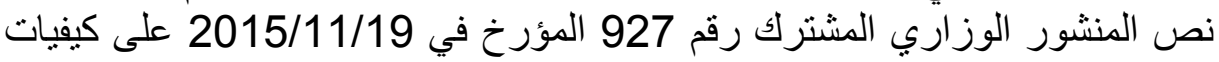

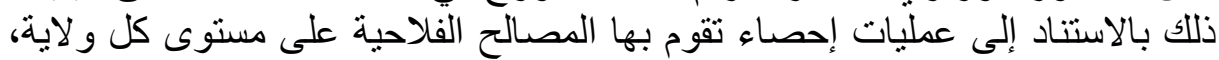

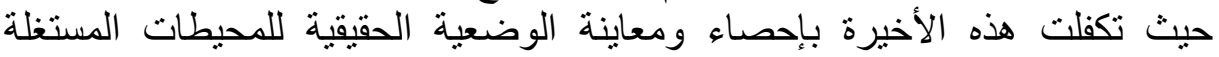

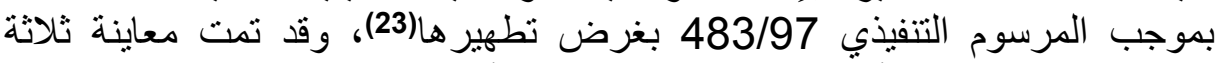

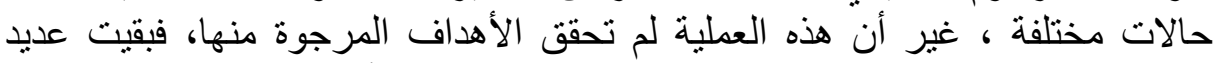

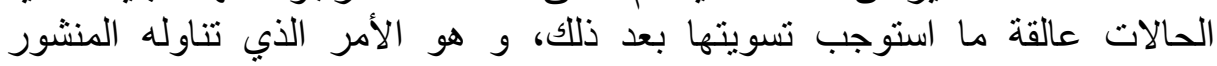

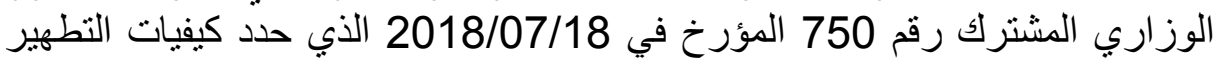

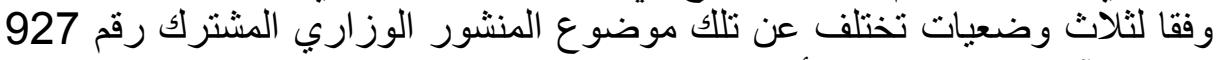

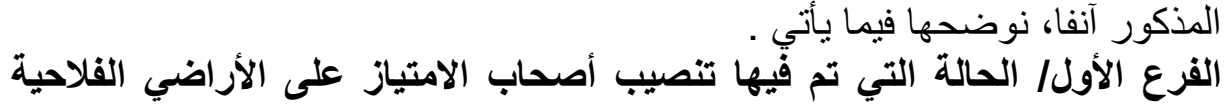

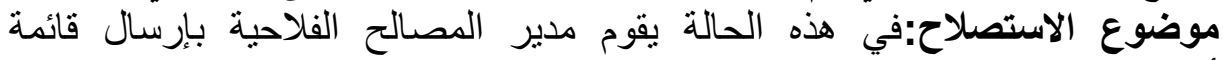

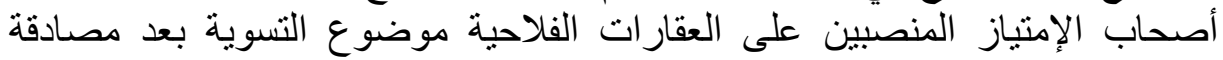

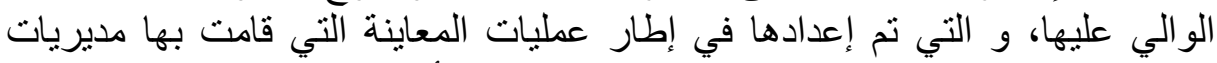

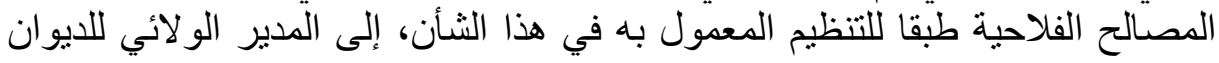


الوطني للأراضي الفلاحية، الذي يستدعي بدوره أصحاب الإمنياز لإمضاء دفتر

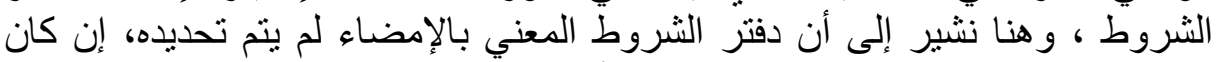

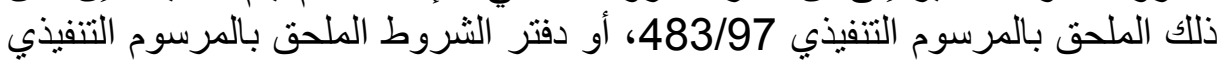

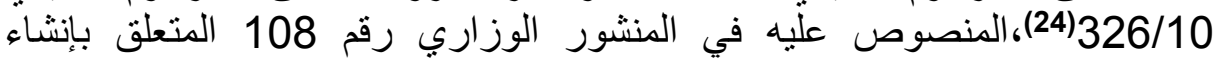

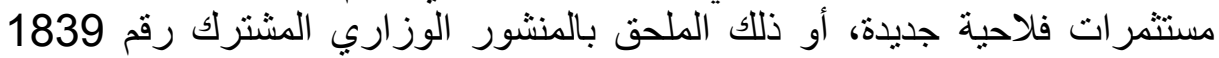

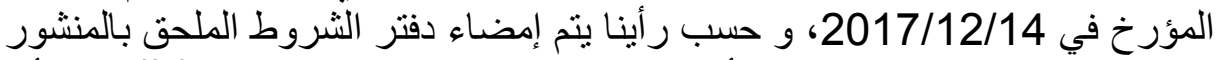

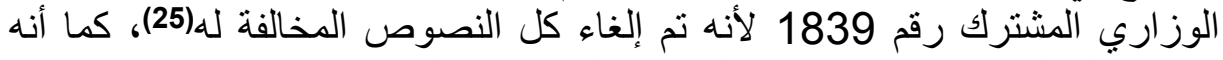

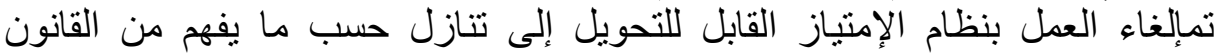

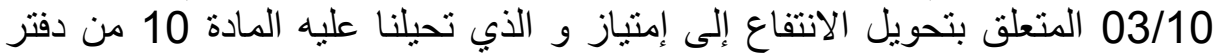

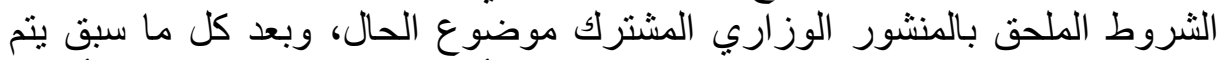

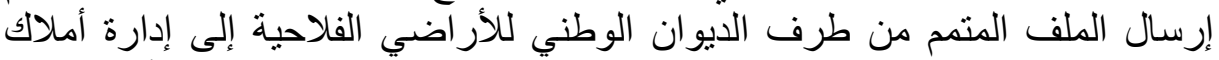

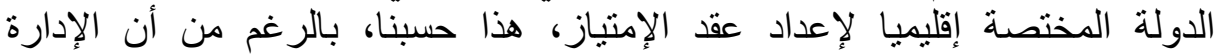

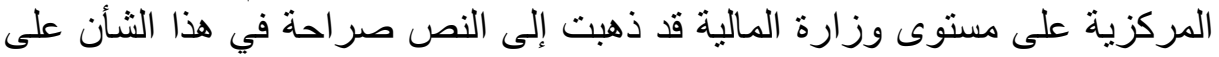

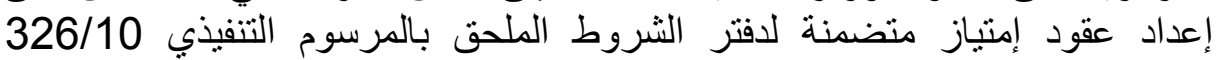

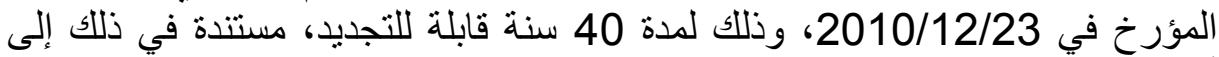

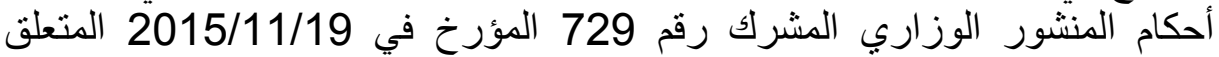

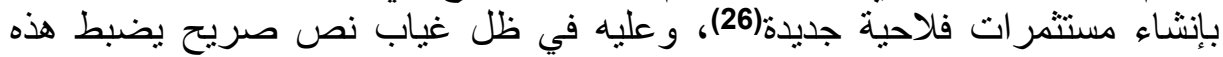

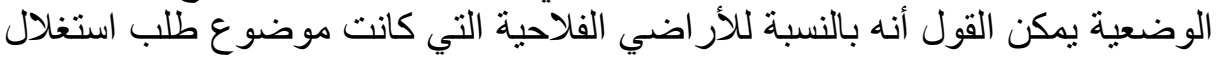

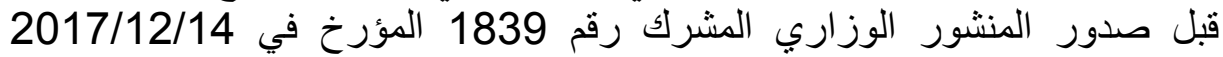

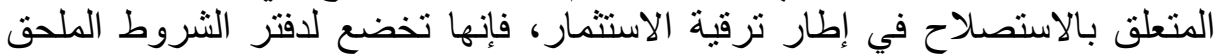

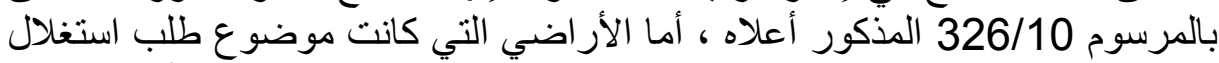

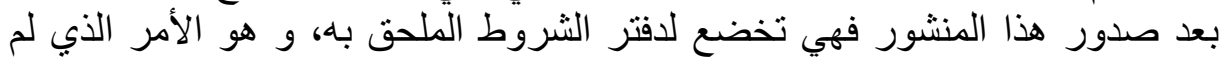

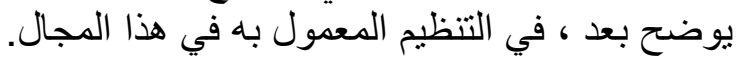

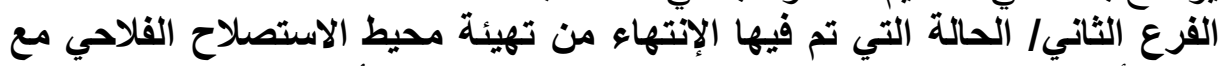

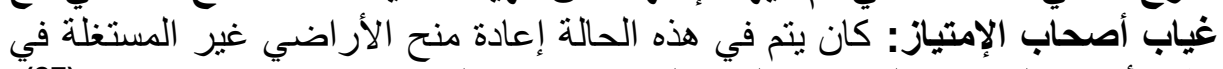

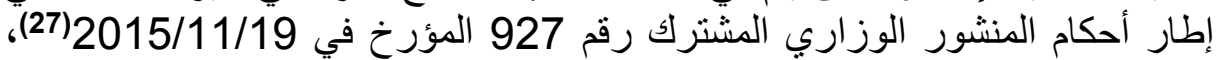

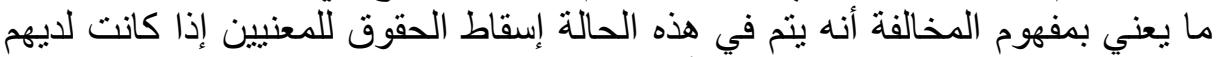

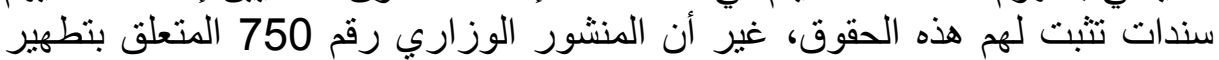

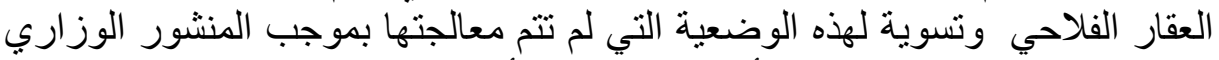

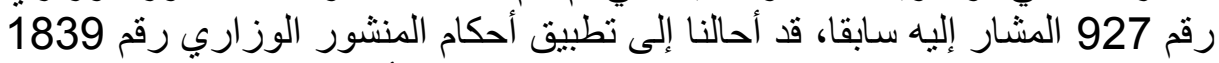

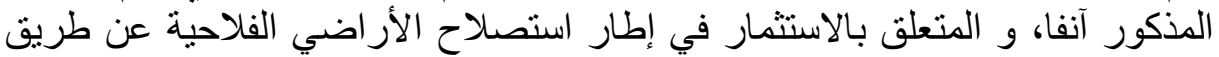

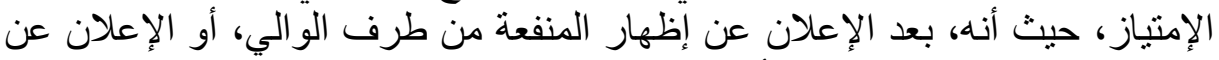

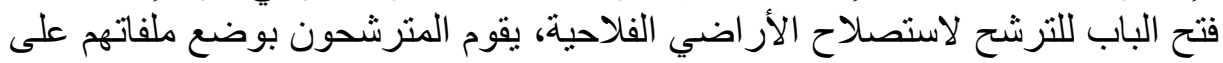

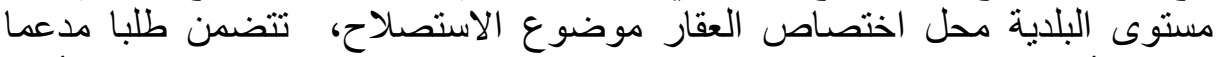

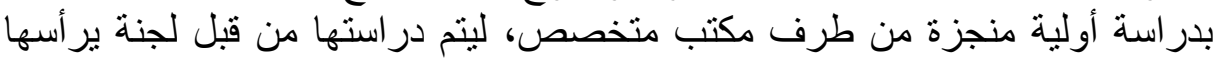

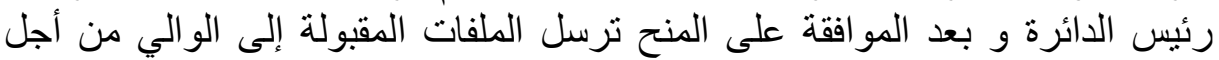

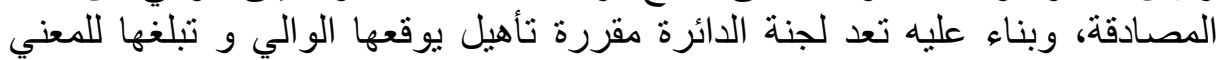

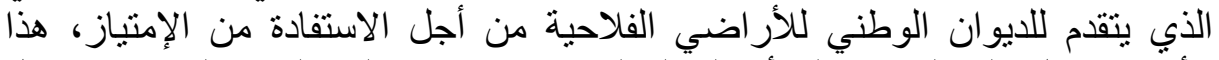

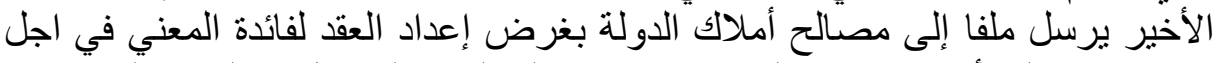

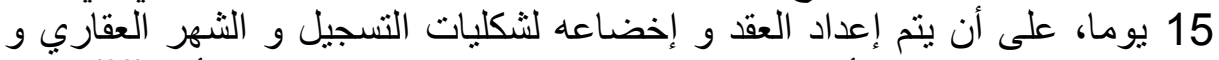

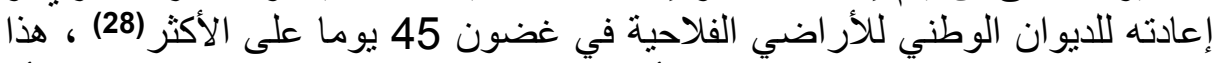

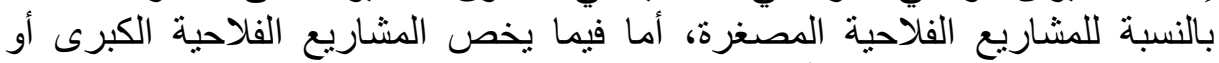

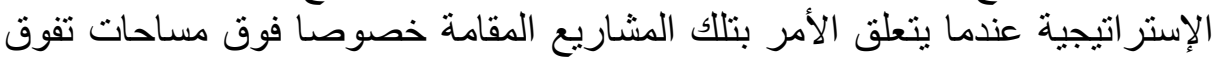




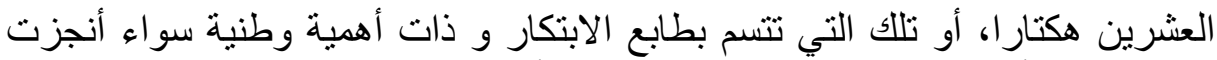

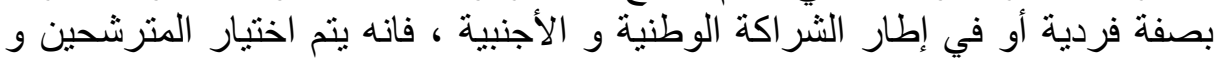

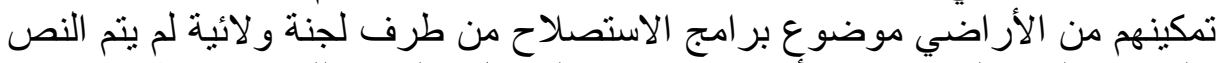

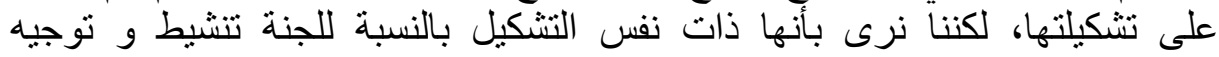

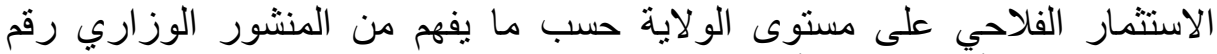

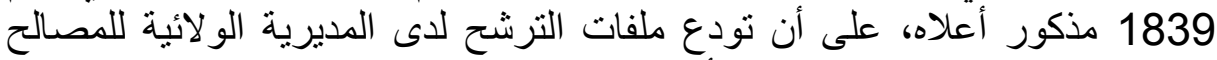

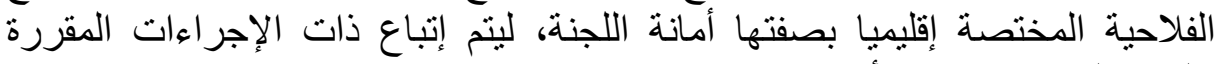

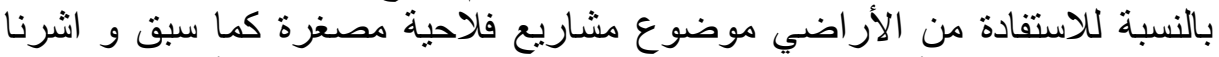

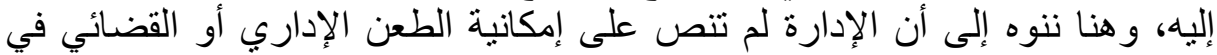

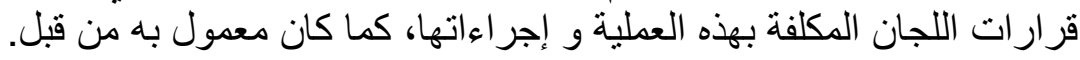

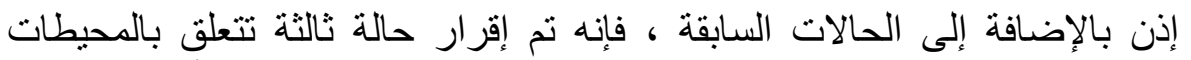

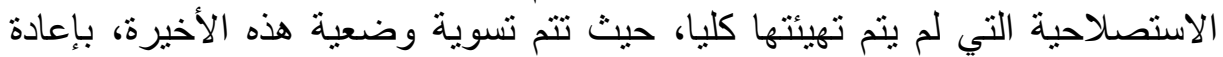

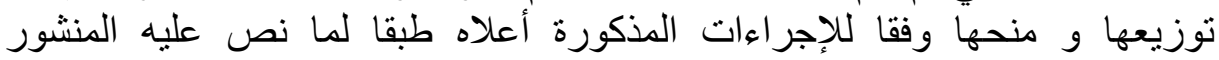

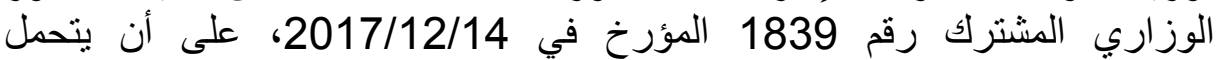

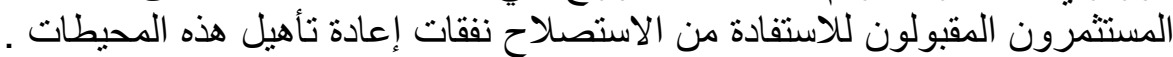

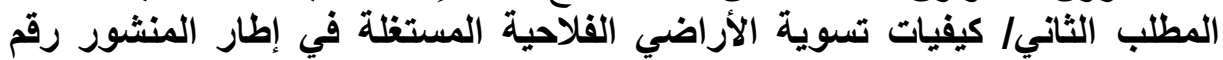

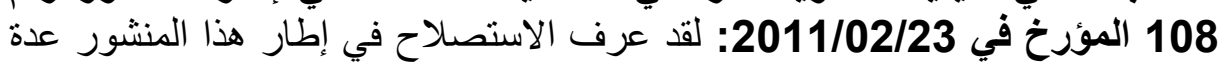

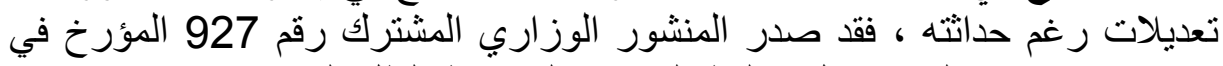

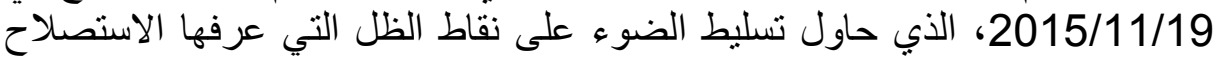

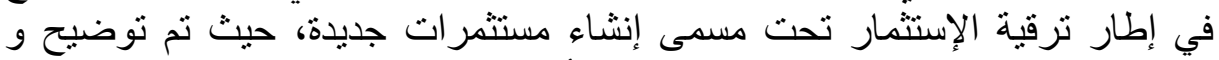

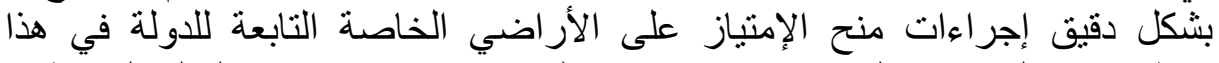

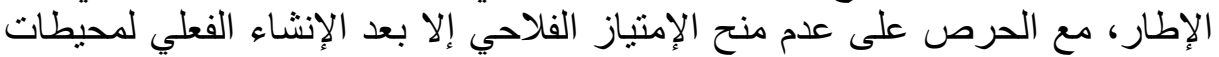

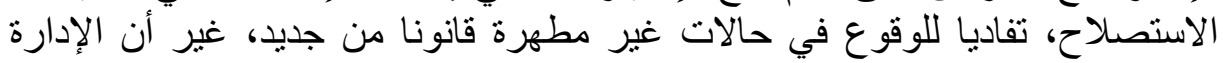

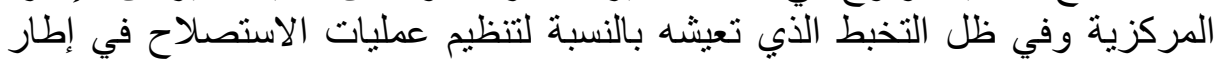

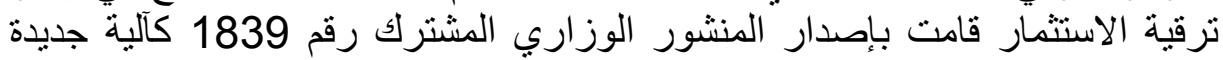

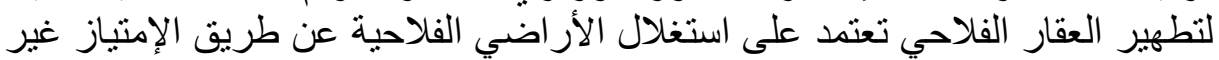

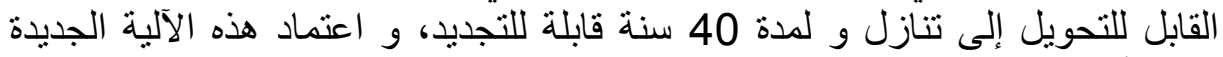

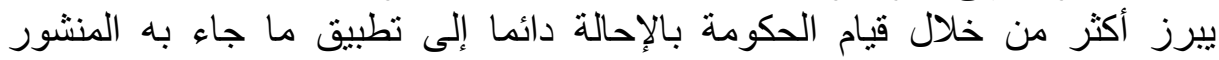

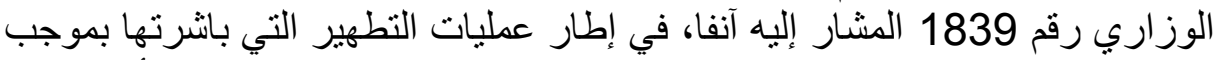

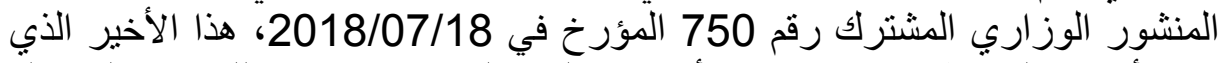

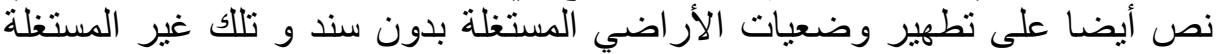

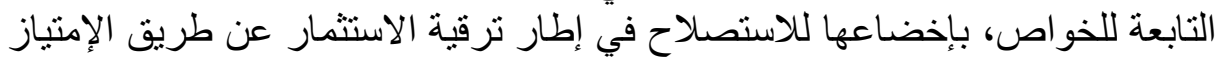

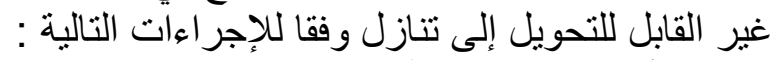

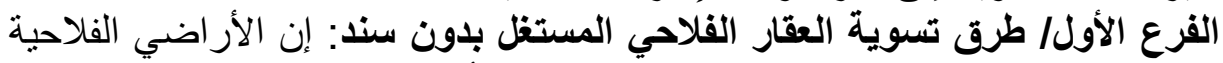

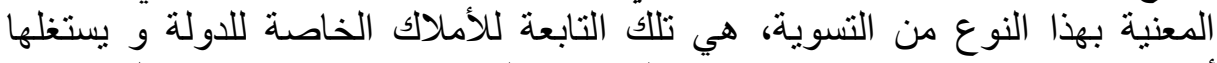

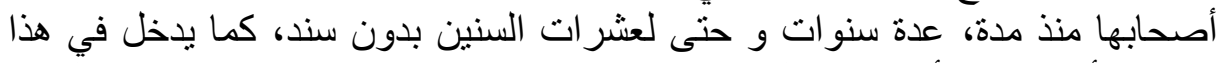

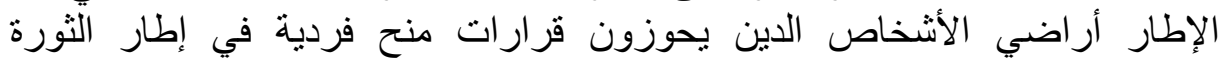

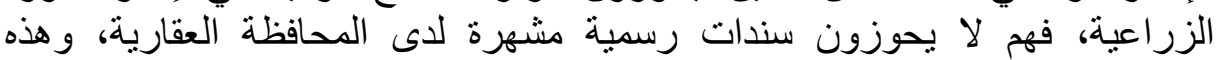

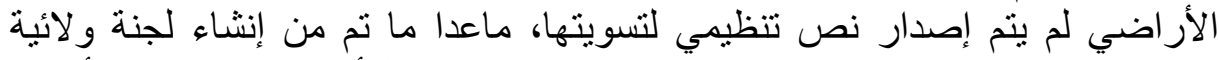

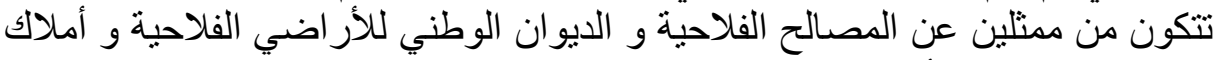

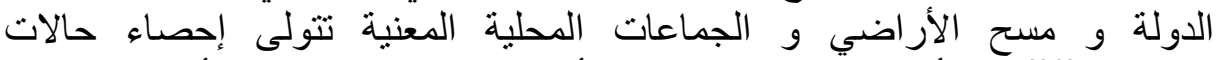

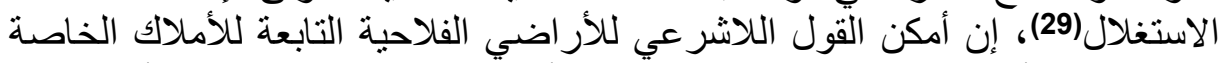

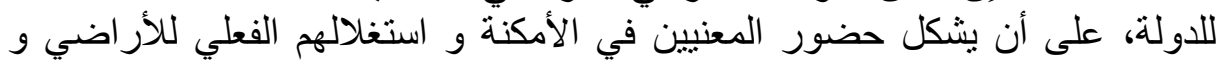

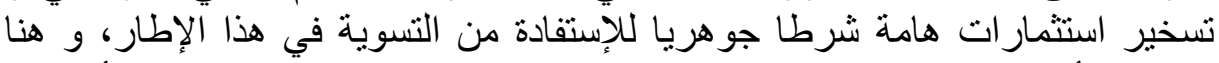

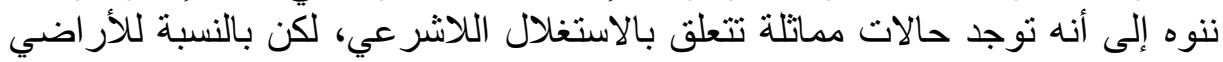


الواقعة داخل مساحات الاستصلاح المحددة بعنوان القانون 18/83 المتعلق بحيازة

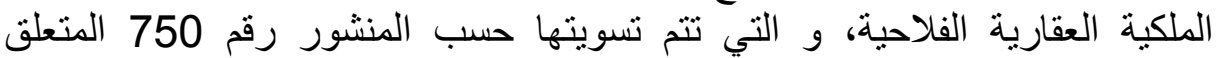

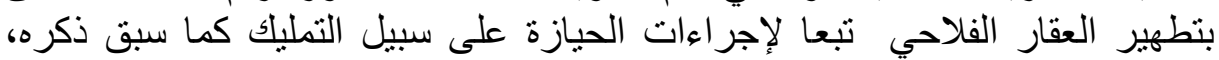

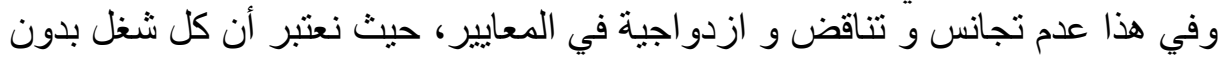

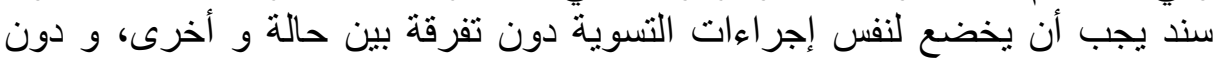

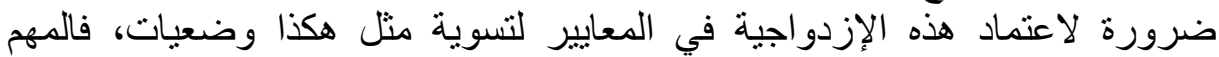

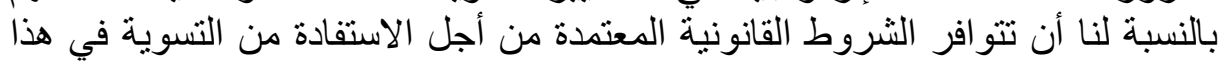
المجال.

الفرع الثاني/ طرق تسوية العقار الفلاحي غير المستغل المملوك من طرف الخواص:

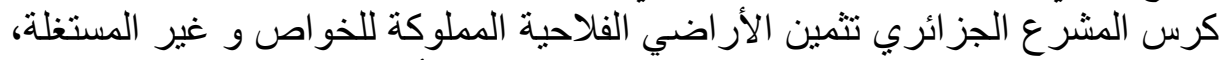

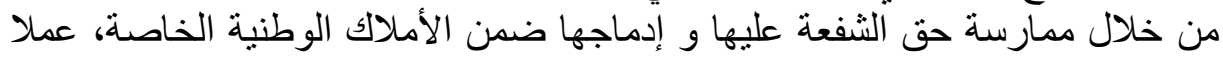

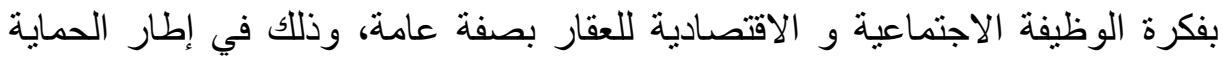

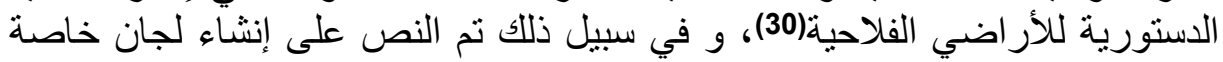

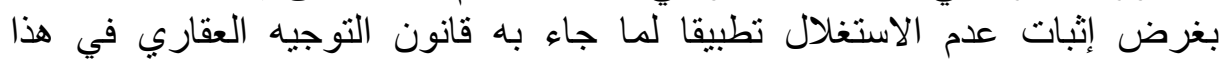

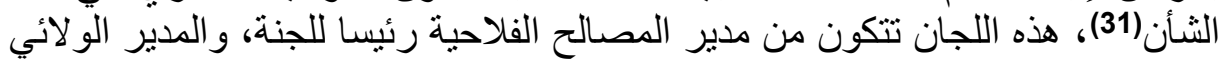

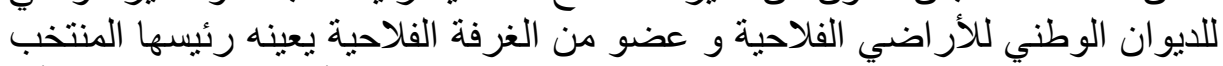

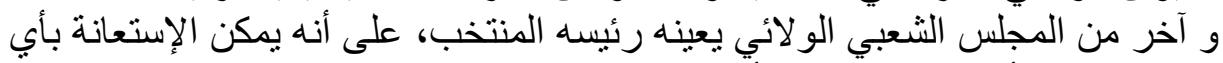

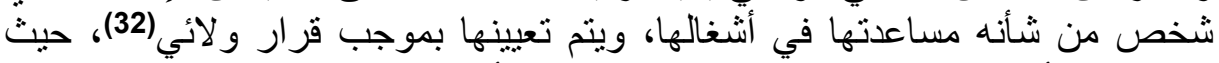

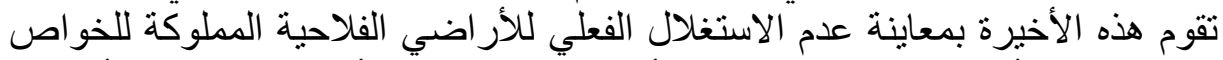

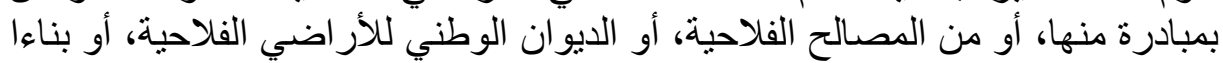

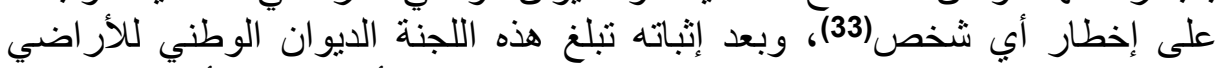

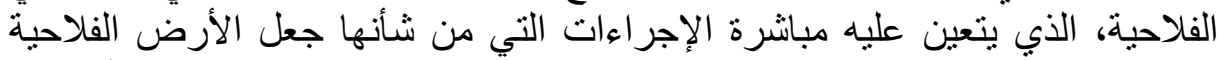

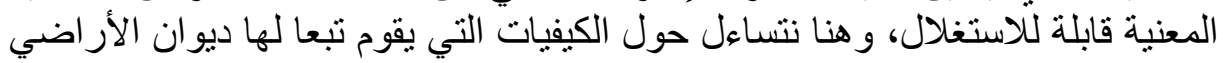

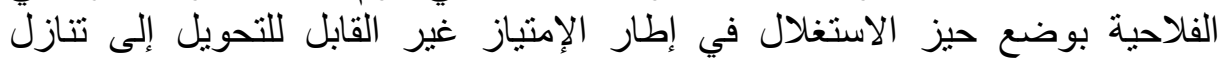

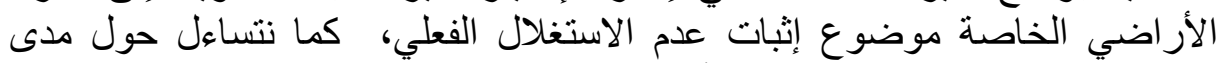

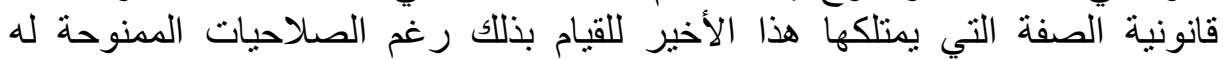

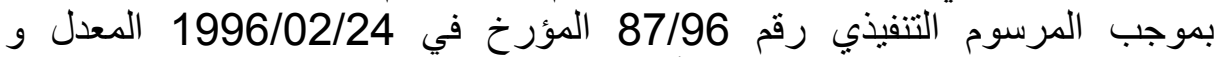

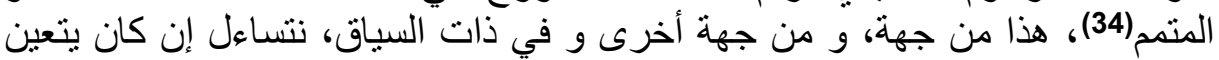

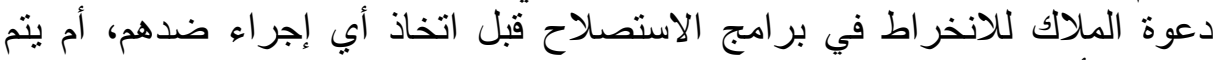

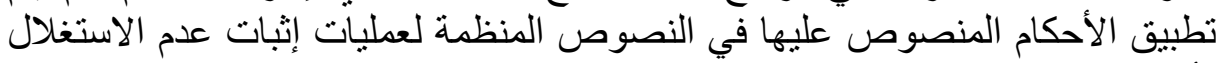

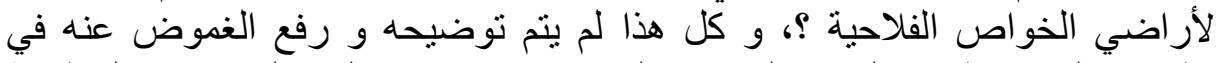

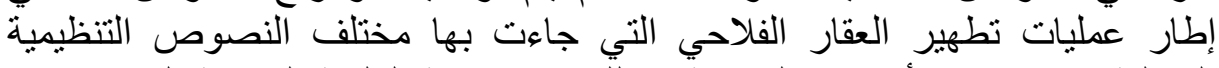

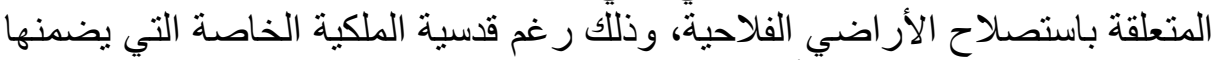

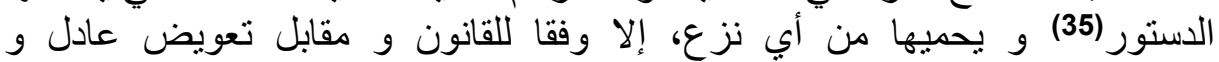

منصف(36)

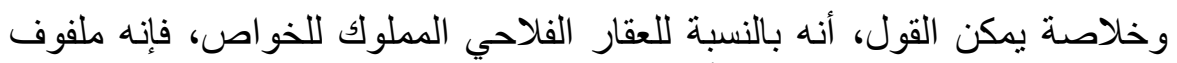

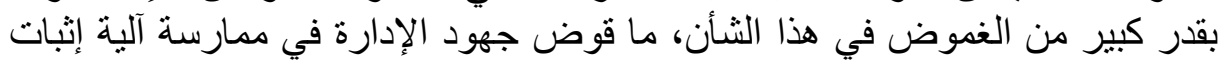

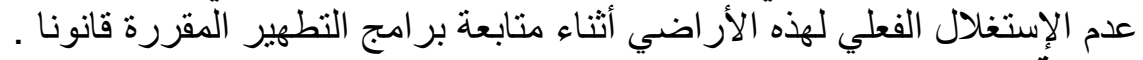

الخاتمة:

إن دراسة الاستصلاح الفلاحي ضرورة فرضها التوجه العام للاولة الجزائرية في

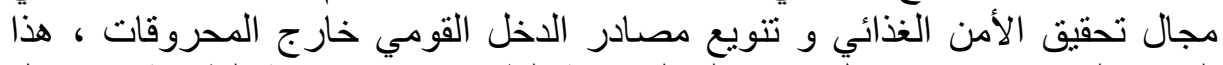

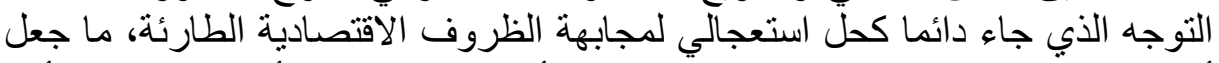

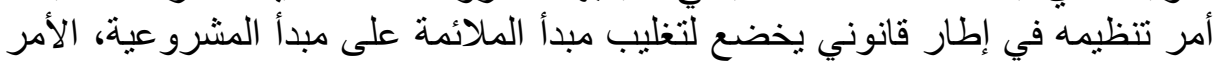


الذي أدى إلى تبلور وضعيات مادية و قانونية معقدة مما يتطلب تسويتها، و هو ما

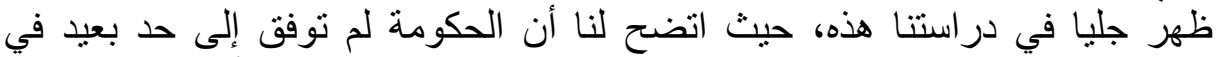

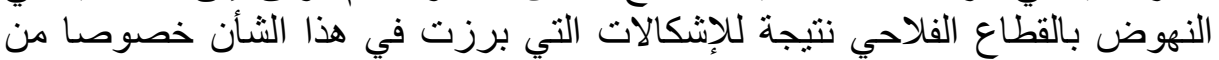

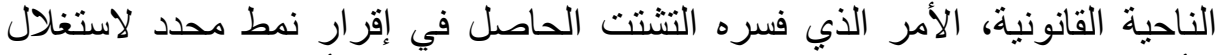

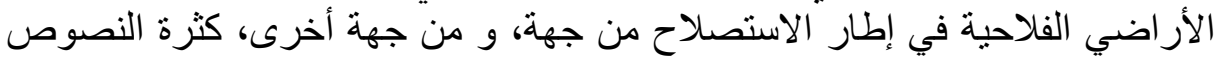

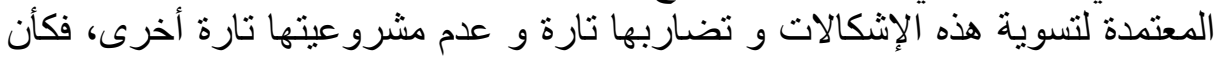

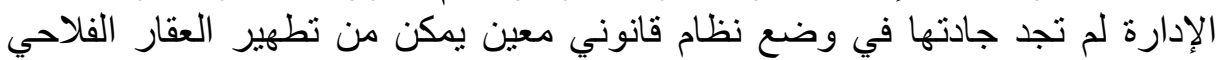

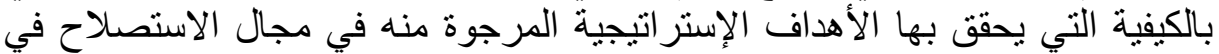

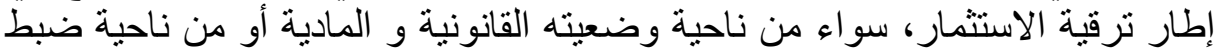

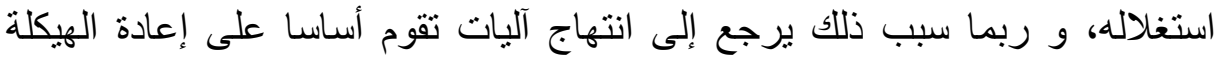

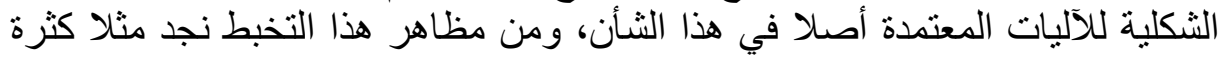

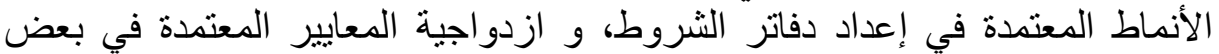

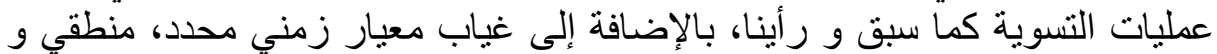

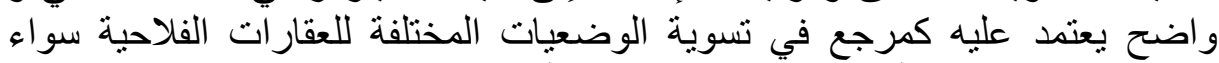

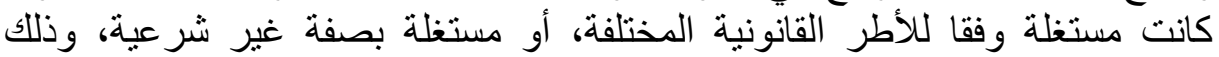

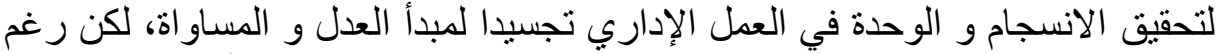

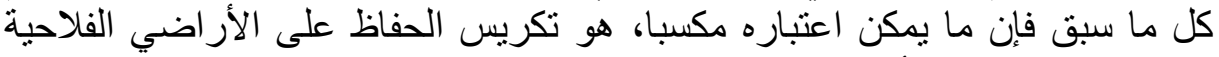

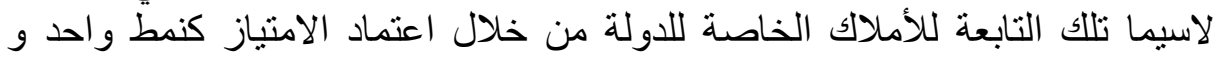

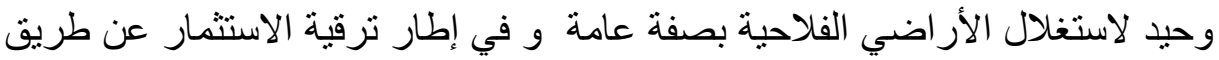

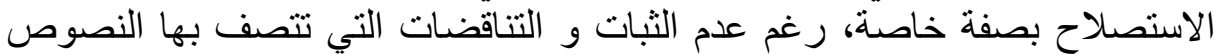

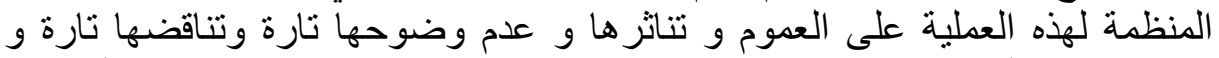

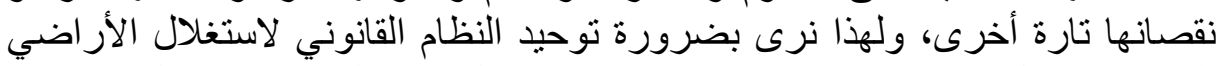

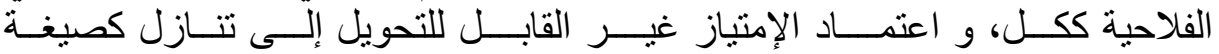
وحيدة يتـــم بمقتضـــاها استغلال هذه الأخيرة، بما يحقق تجانس و فعالية في تسوية الإنة

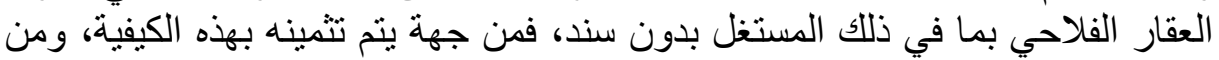

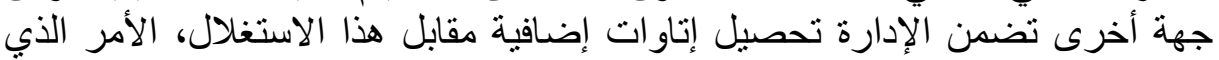

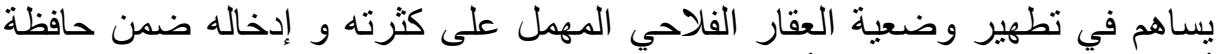

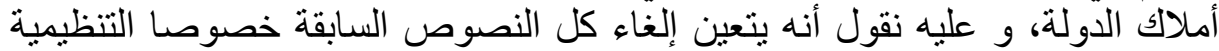

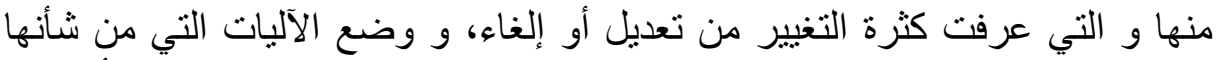

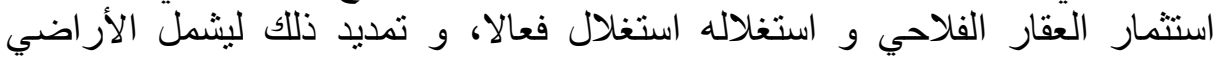

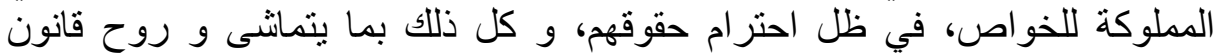

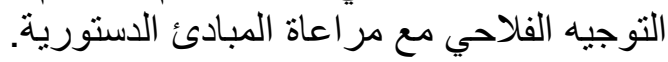
التهميش:

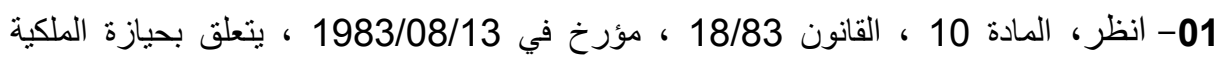

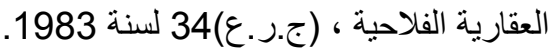

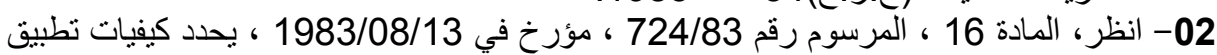
القانون 18/83 المؤرخ في 1983/08/13 ، 1983 ، يتعلق بحيازة الملكية العقارية الفلاحية ،

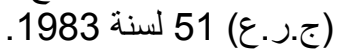
03- انظر ، التعليمة رقم 5627 ، مؤرخة في 2011/05/23 ، نتعلق بحيازة الملكية العقارية

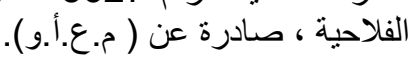
04- انظر ، المادة 02 ، القانون رقم 18/83 ، 18/85 ، المرجع السابق

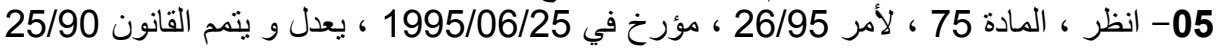

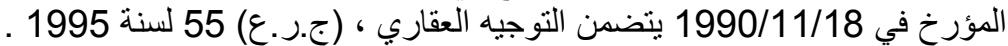

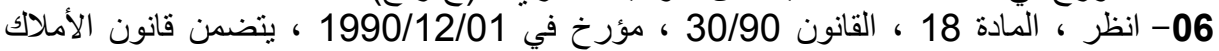
الوطنية، (ج.ر.ع) 52 لسنة 1990 ل 180 
07- انظر ، التعليمة رقم 7322 ، مؤرخة في 2009/06/09 ، تلتعلق بحيازة الملكية العقارية

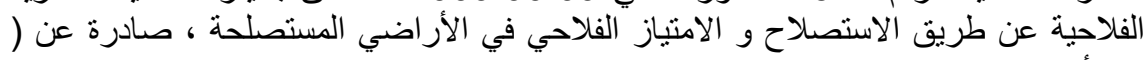

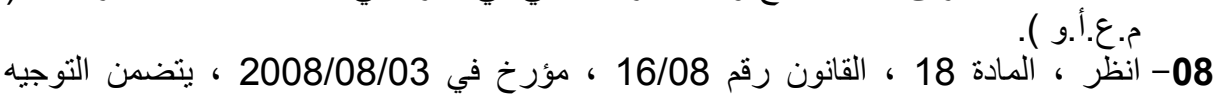

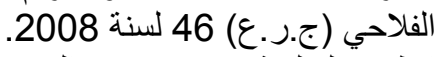
09- انظر ، التعليمة رقم 7322 ، 732 ، المرجع نفسه .

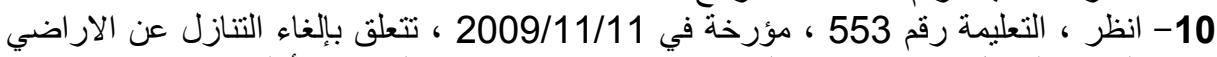

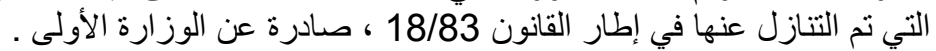
11- انظر ، المادة 21 ، القانون رقم الطمار القان 18/83 ، المرجع السابق.

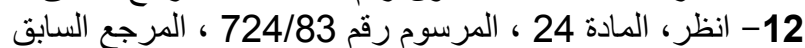

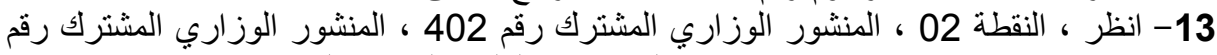
402 ، مؤر خ في 2011/06/02 ، الفطة ، بنعلق بحيازة الملكية العقارية الفلاحية.

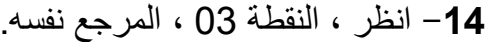

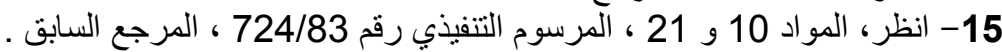

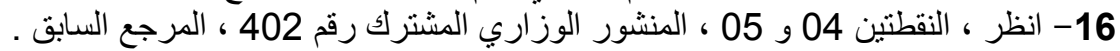

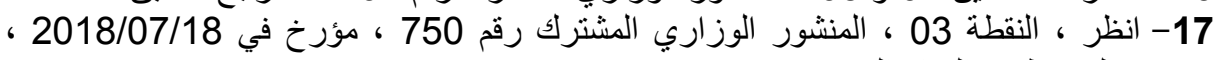

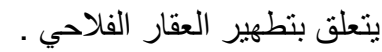

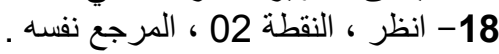

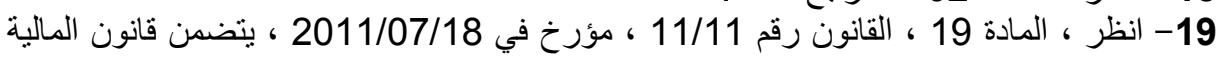

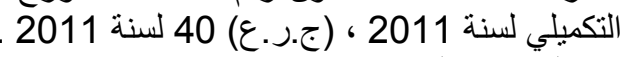

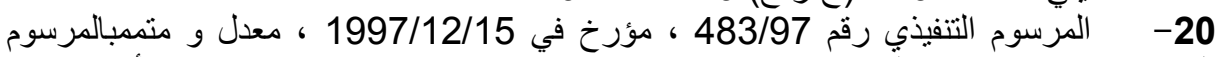

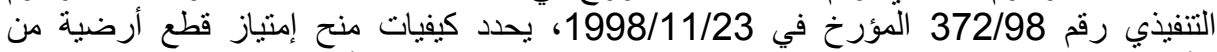

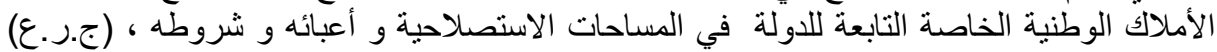
(السنة 83 21- المنشور الوزاري المشترك رقم 108 ، مؤرخ في 2011/02/23 ،معدل و متمم يتعلق بإنشاء مستثمر ات جديدة.

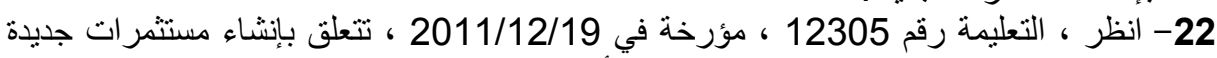

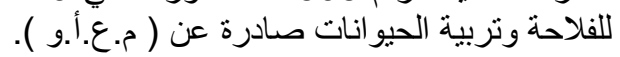

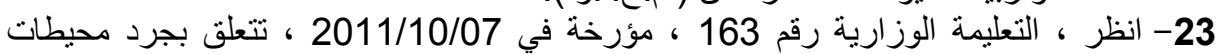
الاستصلاح الفلاحي ، صادرة عن وز النية ارة الفلاحة و التنمية الريفية.

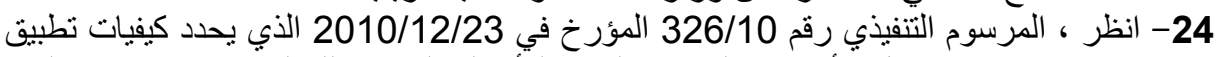
حق الامتياز لاستغلال الأراضي الفلاحية التابعة للأملاك الخاصة للاولة ، (ج.ر.ع) 79 لسنة 2010 25- انظر ، المنشور الوزاري المشترك رقم 1839 ، مؤرخ في 2010 2017/12/14 ، ينعلق بالاستفادة من العقار الفلاحي التابع للأملاك الخاصة للادولة و المخصص النص للاستثمار في إطار الاستصلاح عن طريق الامتياز.

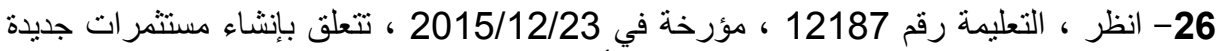

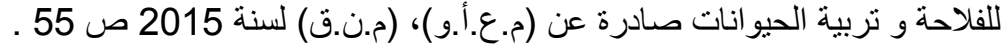

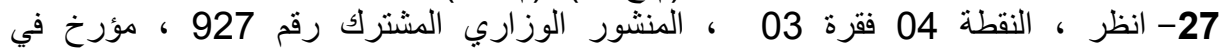

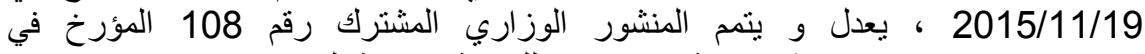

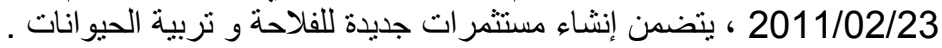

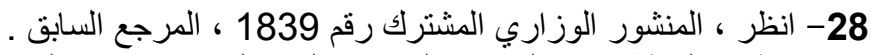

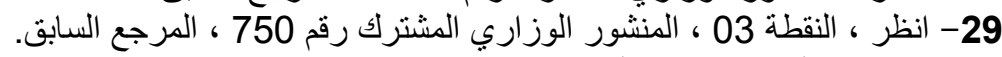

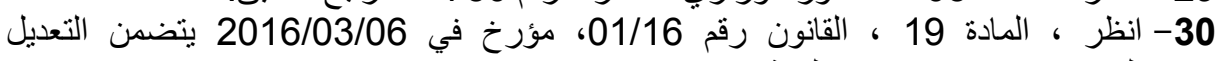

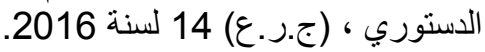

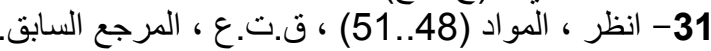

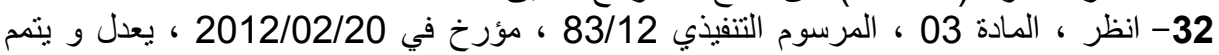

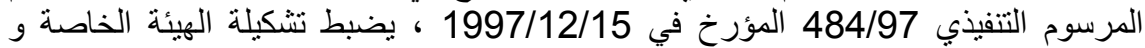

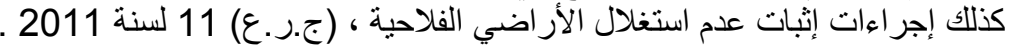
33- 33 انظر ، المادة 04 ، المرجع نفسه. 


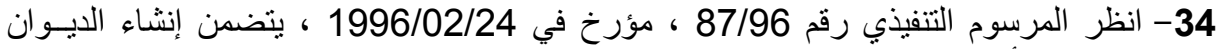

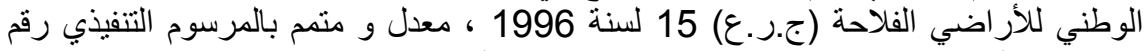

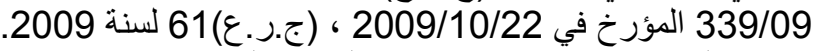
35- انظر ، المادة 64 ، ، دستور في 2016 ، المرجية ، المرجع السابق . 36- 36 - انظر ، المادة 22 ، المرجع نفسه.

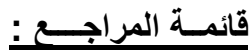
أولا/النصوص القانونية: أر النصوص التثريعية:

- - القانون 18/83 ، مؤرخ في 1983/08/13 ، بتعلق بحيازة الملكية العقارية الفلاحية ،

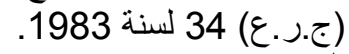
القانون رقم 25/90 ، مؤرخ في 1990/11/18 ، بتضمن التوجيه العقاري المعدل و المتمم

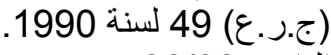

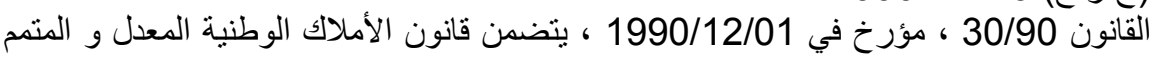

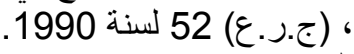

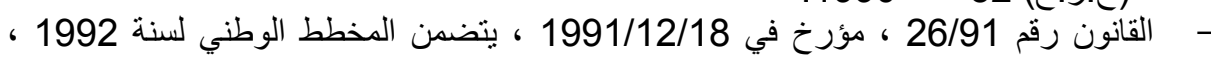

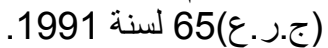

الأمر 26/95 ، مؤرخ في 1990/11/18

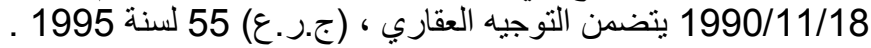
القانون رقم 16/08 ، مؤرخ في 2008/08/03 ، يتضمن التوجيه الفلاحي (ج.ر.ع) 46 لسنة 2008 - - القانون رقم 11/11 ، مؤرخ في 2011/07/18 ، يتضمن قانون المالية التكميلي لسنة 2011 ،

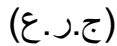

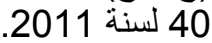
- 101/16 القانون ، مؤرخ في 2016/03/06 يتضمن التعديل الدستوري ، (ج.ر.ع) 14 -

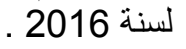

\section{ب/ النصوص التظيمية :}

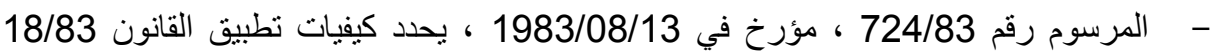

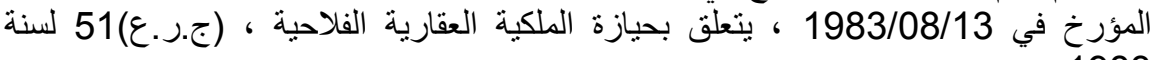
1983

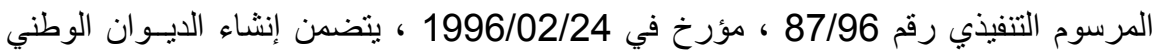

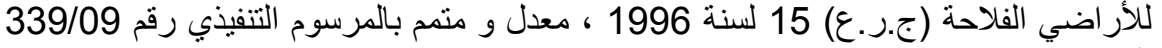

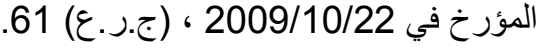
لسنة 2009.

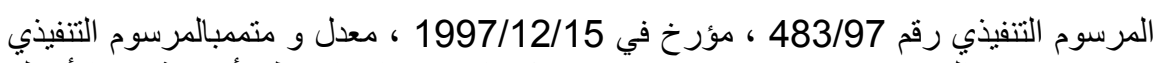

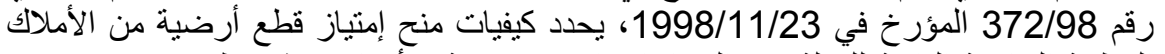

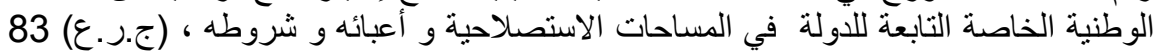
ل السنة 1997.

المرسوم التنفيذي رقم 326/10 المؤرخ في 2010/12/23 ، يحدد كيفيات نطبيق حق الامتياز

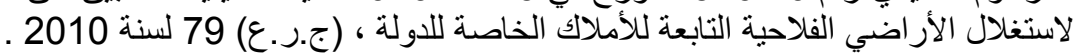

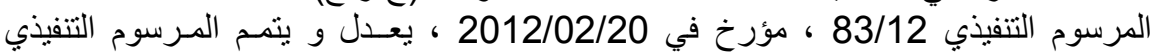

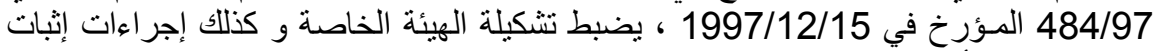

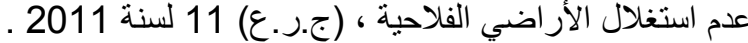
المنشور الوزاري المشترك رقم 108 ، مؤرخ في 2011/02/23 ، يتعلق بإنشاء مستثمرات لري المثترك رق 402 ، مؤرخ في 2011/06/02 ، يتعلق بحيازة الملكبة

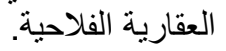




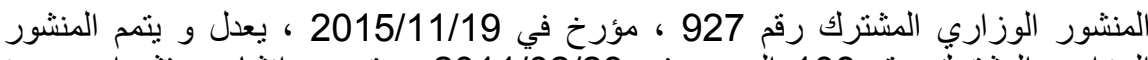

الوزاري المشترك رقم 108 المؤرخ في 2011/02/23 ، يتضمن إنشاء مستثمر ات جديدة

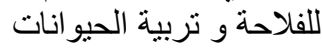

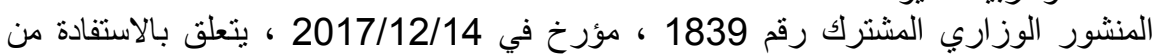
العقار الفلاحي التابع للأملاك الخاصة للاولة و و المخصص للاستثمار في إطار الاستصلاح عن

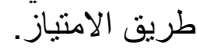
المنشور الوزاري المشترك رقم 750 ، مؤرخ في 2018/07/18 ، يتعلق بتطهير العقار

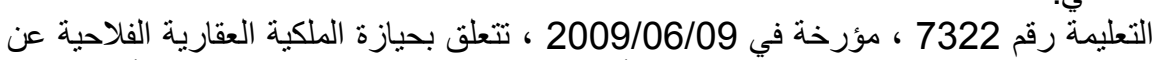

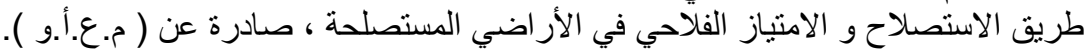

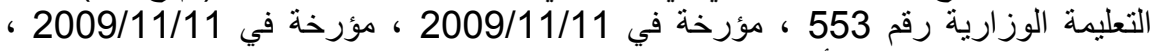
تتعلق بإلغاء التنازل عن الأراضي التي نم التنازل عنها في إطار القانون 18/83 ، صيادرة عن

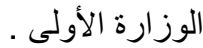
التعليمة رقم 5627 ، مؤرخة في 2011/05/23 ، تتعلق بحيازة الملكية العقارية الفلاحية ،

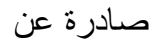

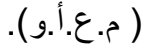

التعليمة الوزارية رقم 163 ، مؤرخة في 2011/10/07 ، تتعلق بجرد محيطات الاستصلاح الفلاحي ، صادرة عن وزارة الفلاحة و التنمية الريفية.

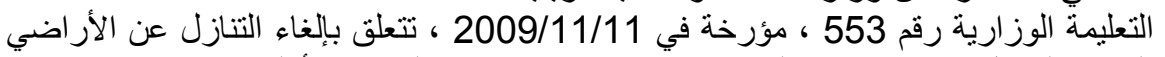

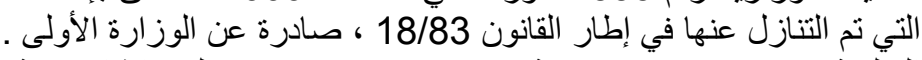

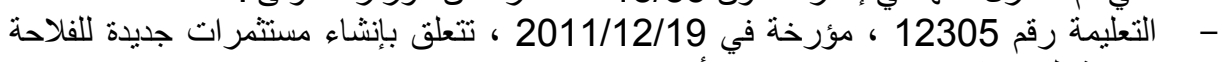
وتربية الحيو انات ، صادرة عن (م.ع.أ.و ).

ثانيا/ المؤلفات القانونية :

- مجمع النصوص القانونية لسنة 2015 ، صادر عن ( م.ع.أو ) ) .

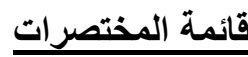

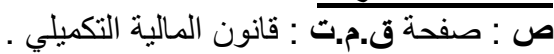
ق.ت.ع : قانون التوجيه العقاري ـم.ع.أو.و : المديرية العامة للأملاك الوطنية .

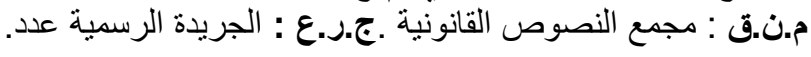

